\title{
EFEITO DA RADIOTERAPIA, QUIMIOTERAPIA E QUIMIORADIOTERAPIA NA DENTINA RADICULAR APÓS ERosão, CÁrie e Abrasão
}

\begin{abstract}
Dissertação apresentada à Faculdade de Odontologia de Ribeirão Preto da Universidade de São Paulo para obtenção do título de Mestre em Ciências Programa: Odontologia Restauradora - Área de concentração: Odontologia Restauradora - Opção: Dentística
\end{abstract}

Orientadora: Profa. Dra. Regina Guenka Palma-Dibb 
Autorizo a reprodução e divulgação total ou parcial deste trabalho, por qualquer meio convencional ou eletrônico, para fins de estudo e pesquisa, desde que citada a fonte.

Ficha catalográfica preparada pela Seção de Tratamento da Informação do Serviço de Biblioteca

Fillus, Thaís Marilia.

Efeito da Radioterapia, Quimioterapia e Quimioradioterapia na Dentina Radicular após Erosão, Cárie e Abrasão. Ribeirão Preto, 2017.

104p.: il.

Dissertação (Mestrado) - Universidade e São Paulo, 2017.

Orientadora: Palma-Dibb, Regina Guenka.

1. Radioterapia. 2. Quimioterapia. 3. Dentina. 4. Cárie dentária. 5. Erosão dentária.

6. Abrasão Dentária. 
Fillus, T. M. Efeito da Radioterapia, Quimioterapia e Quimioradioterapia na Dentina Radicular após Erosão, Cárie e Abrasão. Dissertação apresentada à Faculdade de Odontologia de Ribeirão Preto da Universidade de São Paulo para obtenção do título de Mestre em Ciências.

\section{Banca Examinadora}

Data:

1

Prof. Dr.

Instituição:

Julgamento:

Assinatura:

Prof. Dr.

Instituição:

Julgamento:

Assinatura:

Prof. Dr.

Instituição:

Julgamento:

Assinatura: 



\section{Dedicatória}

Aos meus pais, Duilio e Marcia, pela dedicação na minha educação, pelo incentivo constante e pelo esforço em me proporcionar sempre o melhor.

Sem vocês essa conquista não seria possível!

Ao meu irmão, Bernardo, por ser meu melhor amigo.

Aos meus avós, Vó Tudi, Vô Mário, Vó Mari e Vô Nine, que sempre partilharam das alegrias comigo e torceram pelas minhas conquistas.

Amo muito vocês!!! 



\section{Agradecimentos Especiais}

À Deus, por iluminar meu caminho, dando-me serenidade, força e discernimento para superar as dificuldades de cada dia.

À minha amiga e orientadora, Prof. ${ }^{a}$ Dr. ${ }^{a}$ Regina Guenka Palma-Dibb, exemplo de trabalho, dedicação, inteligência e honestidade. Agradeço por ter aceitado essa orientação me recebendo de braços abertos e também pela oportunidade enorme de conhecimento!

Além da orientação formidável, você foi uma super-mãe durante todo meu mestrado!

Obrigada pelo apoio e carinho!

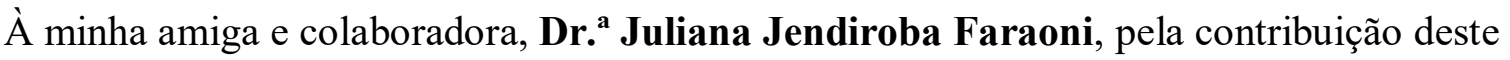
trabalho e pela disponibilidade em todos os momentos. Agradeço a amizade que nasceu dessa vivência!

Ao meu amigo e supervisor de monitoria, Prof. Dr. Vinícius Pedrazzi, que me recebeu na Clínica Integrada e trouxe muito conhecimento, discernimento, acolhimento e alegria aos meus dias!

Á minha melhor amiga, Luana Espig Regiani, por ser meu grande apoio e minha confidente. Obrigada por todos esses anos de irmandade!

Aos meus amigos de Ribeirão Preto, Gabriela Solano, Milagros Sueiro, Tatiana

Carvalho, Daniel Filizola, Shelyn Yamakami, Julia Gallas, Guilherme Pecci, Reinaldo Dias e Isabella Ziotti. Obrigada pela amizade, pelas palavras motivadoras, pelos momentos inesquecíveis que passamos juntos e pela agradável constância e alegria no meu dia-a-dia. Vocês foram minha família aqui!

Aos meus amigos do Paraná, João Henrique Francio Zanini, Jessica Bronoski, Leandro Fabril e Eduardo Fink, que mesmo longe sempre me deram apoio e não me faltaram nos momentos mais difíceis. Sei que sempre poderei contar com vocês. 



\section{Agradecimentos}

À Faculdade de Odontologia de Ribeirão Preto - USP, representada pela Digníssima Diretora Prof. ${ }^{a}$ Dr. ${ }^{a}$ Léa Assed Bezerra da Silva e pelo Vice-Diretor Prof. Dr. Arthur Belém Novaes Júnior.

À Comissão de Pós-Graduação da Faculdade de Odontologia de Ribeirão Preto - USP, na pessoa do Prof. Dr. Manoel Damião de Sousa Neto.

À Coordenação do Programa de Pós-Graduação em Odontologia Restauradora da Faculdade de Odontologia de Ribeirão Preto - USP, na pessoa do Prof. Dr. Manoel

Damião de Sousa Neto.

Ao Chefe do Departamento de Odontologia Restauradora da Faculdade de Odontologia de Ribeirão Preto - USP, na pessoa do Prof. Dr. Ricardo Gariba Silva.

À Fundação de Amparo à Pesquisa do Estado de São Paulo (FAPESP) e à Coordenação de Aperfeiçoamento de Pessoal de Nível Superior (CAPES) pelo apoio e financiamento deste trabalho, (CONVÊNIO FAPESP/CAPES, processo n 2016/17334-7).

Aos professores do Departamento de Odontologia Restauradora da Faculdade de Odontologia de Ribeirão Preto - USP, especialmente à Prof. ${ }^{a}$ Dr. ${ }^{a}$ Silmara Aparecida Milori Corona e à Prof. ${ }^{a}$ Dr. ${ }^{a}$ Aline Evangelista de Souza Gabriel pelo conhecimento, atenção e disposição.

Aos funcionários do Departamento de Odontologia Restauradora da Faculdade de Odontologia de Ribeirão Preto - USP, em especial, ao Carlos, secretário do Curso de PósGraduação em Odontologia Restauradora e à técnica, Patrícia Marchi, do Laboratório de Pesquisa em Dentística pela disponibilidade e amizade.

Aos demais colaboradores deste estudo, Prof. a Dr. a Alexandra Mussolino de Queiróz, Prof. Dr. Leandro Dorigan de Macedo, Prof. Dr. Hélio Massaiochi Tanimoto, Prof. Dr. Luciano Bachmann, Juliana Arid, Denise Freitas, Ana Laura Polizel Ranieri, Emilze Mafra, Larissa Melo Kuil, Raiany Carvalho e Christian Tolentino Dominguez, muito obrigada pela dedicação de todos. Sou muito grata pela oportunidade de trabalhar com vocês.

Aos professores membros desta banca, agradeço a disponibilidade e dedicação do tempo a este trabalho.

Agradeço aos funcionários do Hospital das Clínicas e do Hospital do Câncer de Barretos.

Aos voluntários, agradeço pela paciência, compreensão, dedicação e solidariedade.

Aos pacientes do $\mathrm{HC}$ e do $\mathrm{HCB}$, meu muitíssimo obrigado! Vocês são a alma deste trabalho.

A todos que, de alguma forma, contribuíram para a realização deste trabalho, seja pela ajuda constante ou por uma palavra de amizade. 



\section{Resumo}

Fillus, T.M. Efeito da Radioterapia, Quimioterapia e Quimioradioterapia na Dentina Radicular após Erosão, Cárie e Abrasão. [Dissertação]. 104p. Ribeirão Preto: Faculdade de Odontologia de Ribeirão Preto, São Paulo; 2017.

O objetivo do presente estudo foi avaliar as alterações ocorridas na dentina radicular de dentes permanentes provenientes de pessoas submetidas aos diferentes tratamentos antineoplásicos após erosão (in situ), cárie (in situ) e abrasão (in vitro). Foram selecionados dentes extraídos de pacientes que realizaram tratamentos para câncer na região de cabeça e pescoço (CCP) no Hospital das Clínicas de Ribeirão Preto ou no Hospital do Câncer de Barretos. Os dentes foram divididos em grupos de acordo com o tratamento antineoplásico: CO- controle: dentes extraídos de pacientes saudáveis; RTXradioterapia na região de cabeça e pescoço; QTX - quimioterapia; QRT quimioradioterapia. Todos os fragmentos de dentina radicular foram aleatoriamente distribuídos entre os voluntários de cada fase. Na primeira fase foi realizada a erosão in situ; na segunda fase foi feito o processo carioso nos substratos dentais in situ e na $3^{a}$ fase foi realizado o teste de abrasão por escovação in vitro. As variáveis de resposta quantitativas foram: perfil de desgaste, degrau formado, número, área e perímetro dos túbulos dentinários, rugosidade da superfície, volume perdido e quantificação do tecido desmineralizado; e qualitativamente analisou-se a morfologia da superfície. $\mathrm{Na}$ erosão observou-se que o processo erosivo produziu um aumento no número, diâmetro e área dos túbulos de modo geral, sendo que apenas QRT apresentou maior perda estrutural e diferente estatisticamente em relação aos outros grupos $(p<0,05)$. No processo carioso nenhum tratamento proporcionou alteração quantitativa maior que o controle $(p>0,05)$, contudo morfologicamente foi observado que o tecido dentinário submetido à QRT apresentou uma superfície mais amorfa. Na abrasão, o grupo RTX apresentou maior perda estrutural e diferente estatisticamente de todos os grupos $(p<0,05)$, além de morfologicamente apresentar um maior padrão de desgaste. Conclui-se que os tratamentos antineoplásicos alteraram a dentina radicular e afetaram os processos de erosão, cárie e abrasão.

Palavras-chave: Radioterapia. Quimioterapia. Dentina. Cárie dentária. Erosão Dentária. Abrasão Dentária. 



\section{Abstract}

Fillus, T.M. Effect of Radiotherapy, Chemotherapy and Chemoradiotherapy on Root Dentin after Erosion, Caries and Abrasion. [Dissertação]. 104p. Ribeirão Preto: Faculdade de Odontologia de Ribeirão Preto, São Paulo; 2017.

The aim of the present study was to evaluate the alterations on root dentin of permanent teeth from individuals submitted to different antineoplastic treatments after erosion (in situ), caries (in situ) and abrasion (in vitro).Teeth extracted from patients who underwent cancer treatments in the head and neck region (HNC) at Hospital das Clínicas de Ribeirão Preto or at Hospital do Câncer de Barretos were selected and divided into groups according to antineoplastic treatment: CO-control: teeth extracted from healthy patients; RTX- radiotherapy in the head and neck region; QTX - chemotherapy; QRT chemoradiotherapy. All fragments of root dentin were randomly distributed among the volunteers of each stage. In the first phase, erosion was carried out in situ; in the second phase the carious process was performed on the dental substrates in situ and the third phase was performed the in vitro abrasion test by teeth-brushing machine. The quantitative response variables were: wear profile, step, number, area and perimeter of the dentinal tubules, surface roughness, volume loss and quantification of the demineralized tissue; and qualitatively was analyzed the surface morphology. For the erosive process, it was observed an increase in the number, diameter and area of the tubules for all groups, but only QRT presented greater structural loss with statistical difference in relation to the other groups $(p<0.05)$. For the carious process, no treatment provided a quantitative alteration greater than the control ( $p>0.05)$. However, morphologically, it was observed that the dentinal tissue submitted to QRT presented a surface more amorphous. For the abrasion, the RTX group presented higher structural loss and statistically different from the other groups $(p<0.05)$, besides presenting, morphologically, a higher pattern of wear. It was concluded that the antineoplastic treatments changed the root dentin and affected the processes of erosion, caries and abrasion.

Keywords: Radiotherapy. Chemotherapy. Dentin. Dental caries. Dental erosion. Dental abrasion. 



\section{Lista De Figuras}

Figura 1. Fluxograma dos procedimentos experimentais para indução de erosão in situ

Figura 2. Fluxograma da $1^{\text {a }}$ fase- Indução da erosão in situ 44

Figura 3. Fluxograma dos procedimentos experimentais para indução de cárie in situ

Figura 4. Fluxograma da $2^{\mathrm{a}}$ fase- Indução da cárie in situ............................. 47

Figura 5. Fluxograma da $3^{a}$ fase- Ensaio de abrasão in vitro ......................... 49

Figura 6. Mensuração do perfil de desgaste $(\mu \mathrm{m})$........................................51

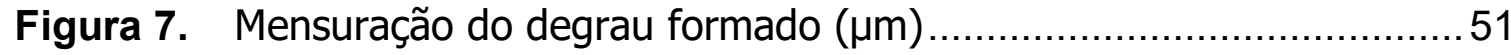

Figura 8. Mensuração do volume perdido $\left(\mu \mathrm{m}^{3}\right)$......................................52

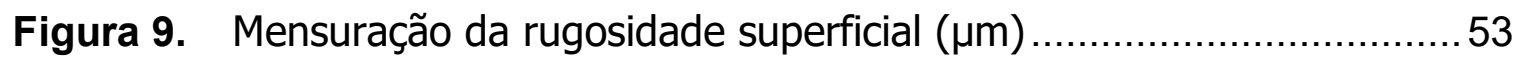

Figura 10. Mensuração da número, área e perímetro dos túbulos dentinários

Figura 11. Quantificação do tecido desmineralizado 55

Figura 12. Gráfico representativo da mediana para volume perdido para a fase de Indução de Erosão

Figura 13. Gráfico representativo da média para número de túbulos para a fase de Indução de Erosão

Figura 14. Gráfico representativo da média para área dos túbulos $\left(e m \mu \mathrm{m}^{2}\right)$ para a fase de Indução de Erosão 60

Figura 15. Gráfico representativo da média para perímetro dos túbulos $(\mathrm{em} \mu \mathrm{m})$ para a fase de Indução de Erosão

Figura 16. Gráfico representativo da mediana para quantificação do tecido desmineralizado para a fase de Indução de Erosão

Figura 17. Dentina radicular, lado esquerdo representa a área referência do espécime (protegida) e o lado direito representa a área exposta ao desafio erosivo 

Figura 18. Dentina radicular, imagens do lado esquerdo representam as análises iniciais dos espécimes e as imagens do lado direito representam as análises após o desafio erosivo.

Figura 19. Gráfico representativo da mediana para volume perdido para a fase de Indução de Cárie 64

Figura 20. Gráfico representativo da mediana para quantificação do tecido desmineralizado para a fase de Indução de Cárie 65

Figura 21. Gráfico representativo da mediana para volume perdido para a fase de Indução de Cárie

Figura 22. Dentina radicular, imagens do lado esquerdo representam as análises iniciais dos espécimes e as imagens do lado direito representam as análises após o desafio cariogênico

Figura 23. Gráfico representativo da mediana para volume perdido para a fase de Abrasão.

Figura 24. Dentina radicular, lado esquerdo representa a área referência do espécime (protegida) e o lado direito representa a área exposta ao desafio abrasivo. 



\section{Lista De Tabelas}

Tabela 1. Tabela de inclusão e exclusão dos dentes para execução do experimento

Tabela 2. Média e desvio padrão dos grupos para perfil de desgaste (Rv em $\mu \mathrm{m})$, degrau formado $(\mu \mathrm{m})$, rugosidade (Sa em $\mu \mathrm{m}$ ) e média, desvio padrão e mediana dos grupos para volume perdido $\left(\mu \mathrm{m}^{3}\right)$ para Indução de Erosão

Tabela 3. Média, desvio padrão e mediana dos grupos para quantificação do tecido desmineralizado para Indução de Erosão.

Tabela 4. Média e desvio padrão dos grupos para perfil de desgaste (Rv em $\mu \mathrm{m})$, degrau formado ( $\mu \mathrm{m})$, rugosidade (Sa em $\mu \mathrm{m}$ ) e média, desvio padrão e mediana dos grupos para volume perdido $\left(\mu \mathrm{m}^{3}\right)$ para Indução de Cárie.

Tabela 5. Médias e desvio padrão dos grupos para a fase de indução de cárie para quantificação do tecido desmineralizado em Tomografia de Coerência Óptica.

Tabela 6. Média e desvio padrão dos grupos para perfil de desgaste (Rv em $\mu \mathrm{m})$, degrau formado $(\mu \mathrm{m})$, rugosidade (Sa em $\mu \mathrm{m}$ ) e média, desvio padrão e mediana dos grupos para volume perdido $\left(\mu \mathrm{m}^{3}\right)$ para Ensaio de Abrasão. 



\section{Sumário}

Resumo

Abstract

Lista de Figuras

Lista de Tabelas

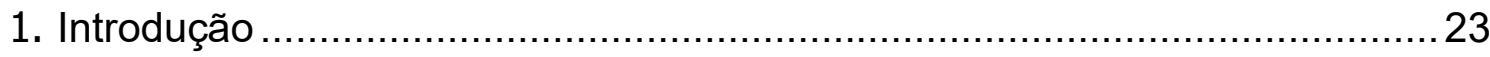

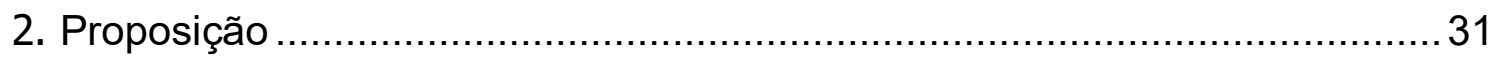

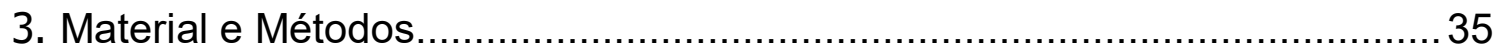

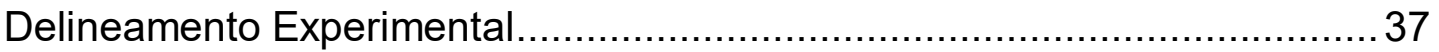

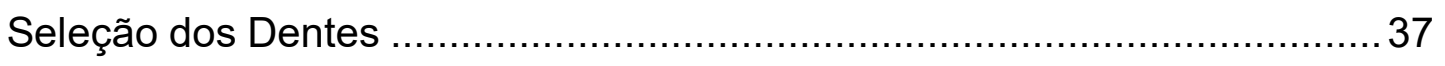

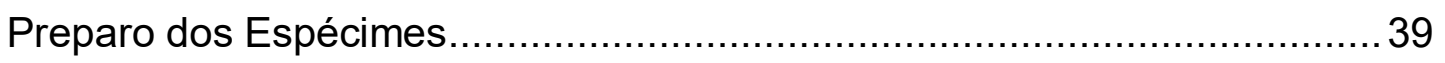

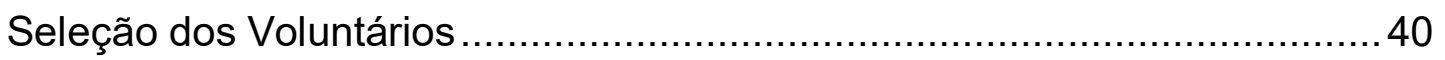

$1^{a}$ fase -Indução da erosão - in situ ..................................................... 42

$2^{\mathrm{a}}$ fase - Indução de lesão de cárie - in situ ........................................... 45

$3^{a}$ fase - Ensaio de abrasão - in vitro ............................................... 48

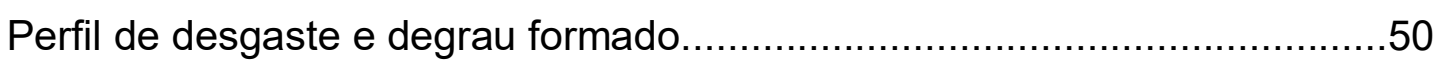

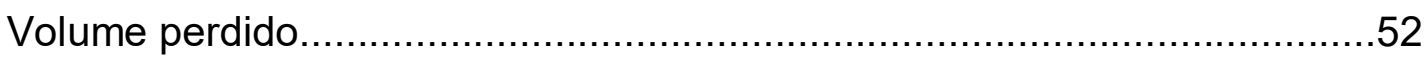

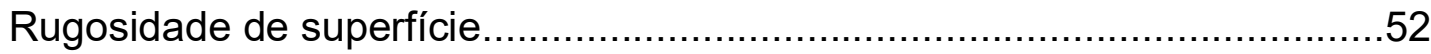

Número, área e perímetro dos túbulos dentinários..................................53

Quantificação do tecido desmineralizado.........................................54

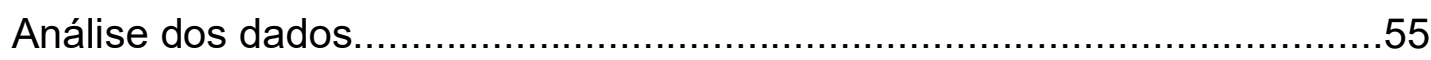

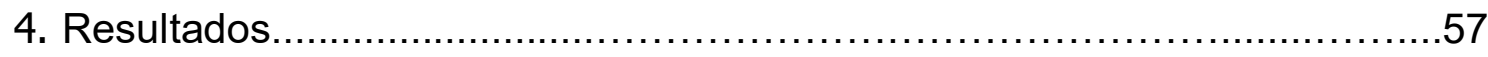

$1^{a}$ fase -Indução da erosão - in situ...........................................................59

$2^{\mathrm{a}}$ fase - Indução de lesão de cárie - in situ............................................64

$3^{a}$ fase - Ensaio de abrasão - in vitro.............................................68

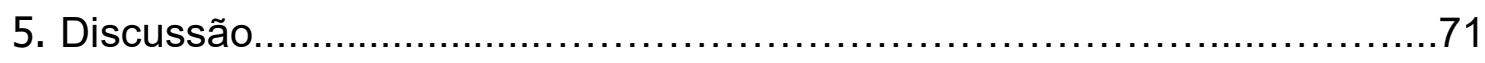

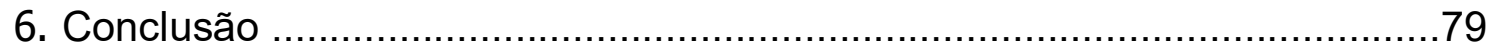

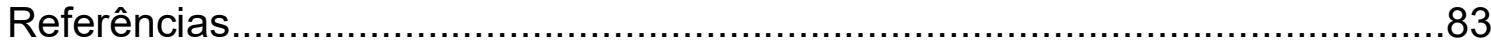

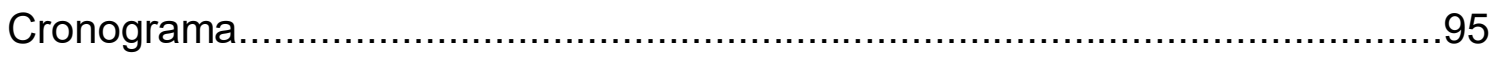

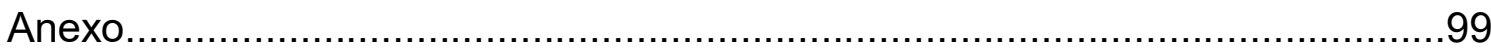



1. Introdução 



\section{INTRODUÇÃO}

O câncer de cabeça e pescoço (CCP) abrange neoplasias malignas localizadas no trato aerodigestivo superior, ou seja, cavidade bucal, faringe e laringe (Dobrossy, 2005), sendo o sétimo tipo de câncer mais comum no mundo (Rettig e D'souza, 2015). O tipo mais comum de câncer de cavidade bucal é o carcinoma de células escamosas (CEC), podendo comprometer até $90 \%$ dos casos (Lemaire et al., 2003; Dobrossy, 2005; Lothaire et al., 2006; Rettig e D'souza, 2015, Inca, 2016, Wu et al., 2017).

O CCP acomete duas a três vezes mais homens do que mulheres (Dobrossy, 2005; Rettig e D'souza, 2015). No Brasil, o Instituto Nacional do Câncer (INCA) estimou para o Brasil, para o biênio 2016-2017, cerca de 600 mil casos novos de câncer, sendo para câncer da cavidade bucal uma estimativa de 11.140 novos casos em homens e 4.350 em mulheres. Ainda segundo esta estimativa, o câncer da cavidade bucal apareceu como o quarto tipo de câncer mais frequente em homens, na Região Sudeste (14,58/100mil). (Inca, 2016). Nos Estados Unidos, a cada dia são diagnosticados 100 novos casos e a cada hora uma pessoa vem a óbito por CCP (Overman, 2009).

Os principais agentes causais externos do CCP estão relacionados ao consumo de álcool e tabaco (Kim et al., 2002; Hashibe et al., 2009; Jemal et al., 2011; Zhou et al., 2013; Gaudet et al., 2015; Rettig e D'souza, 2015; Marur e Forastiere, 2016, Wu et al., 2017), sendo que nestes casos, o risco de desenvolver câncer de cavidade bucal é de aproximadamente 65\% (Inca,2016). $\mathrm{O}$ uso indiscriminado de bebidas alcoólicas, isolado de outros fatores, aumenta a chance absoluta de desenvolvimento de CCP em 1 a 4\% (Hashibe et al., 2007; Hashibe et al., 2009), especialmente na hipofaringe (Menvielle et al., 2004). Porém, o maior risco existe quando o uso de álcool está associado ao de tabaco, pois estes apresentam efeito sinérgico (Blot et al., 1988; Hashibe et al., 2009; Jemal et al., 2011; Rettig e D'souza, 2015).

Somado a isso, desde a década passada, a infecção pelo papiloma vírus humano (HPV), transmitido sexualmente, vem sendo reconhecida também como causa primária do CCP, principalmente de orofaringe, amígdala e base da 
língua, o que pode justificar o aumento da incidência em pacientes mais jovens (Smith et al., 2004; Lothaire et al., 2006; Pintos et al., 2008; Jemal et al., 2011; Marur e Forastiere, 2016; Chowdhury et al, 2017). Embora exista mais de 100 tipos de HPV, apenas uma minoria é considerada de alto risco carcinogênico (Tota et al., 2011), sendo os tipos HPV-16 e HPV-18 responsáveis por cerca de 70 a 90\% dos casos (Herrero et al., 2003; Gillison et al., 2012; Chowdhury et al, 2017).

Os indivíduos diagnosticados com CCP podem ser tratados com cirurgia e/ou radioterapia (RTX) para controle loco-regional, isolados ou combinados à quimioterapia (QTX), denominada de quimioradioterapia (QRT) (Kim et al., 2002; Chan et al, 2013; Qing et al., 2015; Spiotto, 2017). A RTX é amplamente utilizada para o tratamento curativo do CCP, podendo ser indicada como terapia primária ou adjuvante (Adelstein, 2003; Soares et al., 2011; Spiotto, 2017). Há três razões que justificam o uso concomitante da QTX: o intuito da preservação de órgãos; a ação radiossensibilizadora do quimioterápico, afim de um melhor controle local; por potencializar a RTX; e ainda, como parte de uma abordagem combinada, a QTX pode agir sistematicamente na erradicação de micrometástases à distância (Nowara e Suwinski, 2007; Seiwert et al., 2007).

O tratamento radioterápico, embora muito eficaz e realizado da maneira mais conservativa possível, pode levar a efeitos colaterais agudos, geralmente reversíveis; e tardios, que por sua vez são frequentemente irreversíveis e crônicos (Kielbassa et al., 2006). Os principais efeitos colaterais da RTX incluem a mucosite, a xerostomia, a alteração do paladar, a dor orofacial, a alteração do ligamento periodontal, as alterações microvasculares, a necrose de tecidos moles, a osteorradionecrose e a lesão de cárie relacionada à radiação ou "cárie de radiação". Este tipo de lesão de cárie apresenta características singulares diferindo das lesões de cárie convencionais por apresentar progressão rápida e acometer as porções cervicais dos dentes (Kielbassa et al., 2006; Silva et al., 2009; Beech et al., 2014).

Estudos recentes vêm demonstrando que após a RTX ocorrem algumas alterações dos tecidos dentais, tais como destruição de colágeno (Springer et al., 2005; Goncalves et al., 2014), desorganização do esmalte e da dentina resultando em uma superfície dental amorfa (Goncalves et al., 2014; Arid, 2015; 
de Siqueira Mellara, 2016), presença de fendas e túbulos dentinários destruídos e/ou colabados (Gonçalves et al., 2014), alterações da microdureza do esmalte e da dentina (Jansma et al., 1988; Kielbassa et al., 1997; Walker et al., 2011, Goncalves et al., 2014), aumento da solubilidade (Markitziu et al., 1986), atrofia dos processos odontoblásticos, obliteração dos túbulos dentinários (Kielbassa, 2000) e redução da estabilidade da junção amelodentinária (Pioch et al., 1992; Kielbassa et al., 1997).

Além disso, pode promover alterações do esmalte cervical em toda sua profundidade, devido à espessura de esmalte reduzida nesta região (Troconis, 2016). Em dentes permanentes submetidos à radiação, observou-se o aumento da atividade das metaloproteinases da matriz, tanto da região cervical, como na de cúspide e de fundo do sulco; fato este que pode explicar, em parte, o padrão da "cárie de radiação" onde o esmalte parece se destacar da dentina (Bonilla, 2016).

Além dos efeitos colaterais isolados da RTX, a combinação de RTX e QTX pode aumentar a toxicidade desses tratamentos no organismo, conforme observado em diversos estudos clínicos (Trotti et al., 2003; Murphy, et al., 2007; Murphy, Gilbert e Ridner, 2007; Deng et al., 2015). Quanto aos efeitos colaterais, os dados presentes na literatura (Jones e Rankin, 2012) indicam que a QRT provoca essencialmente os mesmos efeitos colaterais da RTX exclusiva em relação à xerostomia e mucosite, porém o desenvolvimento ocorre mais rapidamente e, muitas das vezes, em um grau mais severo.

Tanto a RTX quanto a QTX podem provocar complicações no meio bucal como xerostomia, que podem aumentar o risco de desenvolvimento de lesões de cárie, pela falta da capacidade tampão e lubrificante da saliva, além de dificultar a higienização pela presença de mucosite (Buglione et al., 2016).

O objetivo da quimioterapia é destruir as células neoplásicas por meio de uma substância que altere o funcionamento celular no local tumoral, preservando as células normais. Entretanto, a maioria dos agentes quimioterápicos atuam de forma não-específica, lesando tanto células malignas quanto normais (Almeida, 2005; Krasuska-Slawinska et al., 2016). Chabner e Calabresi descreveram em 1995 a classificação dos fármacos antineoplásicos, eles estariam categorizados em agentes alquilantes, antimetabólitos, antagonistas purínicos, inibidores de 
topoisomerases e produtos naturais.

Dentre os agentes quimioterápicos classificados como agentes alquilantes, têm-se os derivados de platina comumente utilizados no tratamento de CCP, como a Cisplatina. Este composto é considerado o padrão ouro (Altundag, 2005; Bernier, 2006) para tratamento quimioradioterápico para CCP, atuando por meio de ligações covalentes com o DNA, impedindo a sua síntese e reparo, e levando à apoptose da célula cancerígena (Katz et al., 2009; Dasari, 2014; Almeida, 2015). A QRT à base de cisplatina é a primeira escolha para o tratamento de estágios avançados de CCP (Wang, 2016), contudo, devido à falta de seletividade dos agentes quimioterápicos para as células tumorais, é comum a ocorrência de efeitos colaterais gerais como indisposição, redução de peso, diarreia e vômitos (Viele, 2003; Ewens et al, 2005).

Quanto ao impacto da QTX na cavidade bucal, dentre os efeitos colaterais apresentados estão as mucosites, candidose, trismo, náuseas, vômitos, ageusia e alterações salivares quanto ao fluxo e composição (Naidu et al.,2004; Amaral, 2009; Simões et al, 2009; Araújo, 2015; Jesus, 2016; Paiva, 2016; Morais, 2017). Já foi demonstrada correlação entre a quimioterapia e a incidência de lesões cariosas em esmalte, possivelmente limitadas ao momento em que a droga foi administrada aos pacientes, sendo agravada pelos quadros de vômitos, os quais promovem a intensificação da desmineralização do esmalte e a formação da lesão de cárie associada à erosão do tecido (KrasuskaSlawinska et al., 2016), contudo não há até o momento nenhum estudo sobre os efeitos dos agentes quimioterápicos liberados no meio bucal sobre a estrutura dentinária.

Atualmente as taxas de sobrevida e de cura do CCP têm aumentado (Nekhlyudov et al., 2017; Wang et al., 2017), isso se dá em função ao diagnóstico precoce da doença bem como aos avanços nos tratamentos (Tsai et al., 2016; Eskiizmir et al., 2017). Em função do aumento desta taxa de sobrevida, cada vez mais pacientes convivem com os efeitos colaterais pós RTX, QTX e QRT. Embora esta seja uma área muito importante, afim de que os profissionais de saúde possam contribuir para a melhoria da qualidade de vida dos pacientes, a mesma é pouco explorada, não havendo estudos até então que relacionem os processos dentais básicos como os de desmineralização-remineralização e de 
desgaste abrasivo com os efeitos colaterais dos tratamentos para CCP.

Sabendo das alterações ocasionadas na cavidade bucal pela radioterapia, quimioterapia e quimioradioterapia, o objetivo do presente estudo foi analisar as alterações superficiais sofridas pela dentina radicular de dentes permanentes de pessoas submetidas à radioterapia e/ou quimioterapia; avaliar, in situ, a erosão e indução de cárie na dentina radicular; e avaliar, in vitro, a resistência à abrasão por escovação do substrato. 

2. Proposição 



\section{ProposiçÃo}

O objetivo do presente estudo foi avaliar as alterações ocorridas na dentina radicular de dentes permanentes de pessoas submetidas à RTX, QTX ou QRT, após indução da erosão e da lesão de cárie, in situ; e avaliar, in vitro, a resistência abrasiva à escovação. 

3. Material e Métodos 



\section{Material e Métodos}

O presente estudo foi aprovado pelo Comitê de Ética em Pesquisa da Faculdade de Odontologia de Ribeirão Preto (Anexo A) sob o protocolo 61308416.4.0000.5419.

\section{Delineamento Experimental}

O presente estudo foi fatorial $4 \times 1$ tendo fator tratamento em 4 níveis controle (sem nenhum tipo de tratamento), pós radioterapia, pós quimioterapia, pós quimioradioterapia em dentina radicular. Foram 3 grupos experimentais e 1 controle com fragmentos de dentina radicular humana procedentes de pacientes que foram submetidos aos 3 tipos de tratamentos antineoplásicos.

As análises foram realizadas em três fases: primeira fase foi a simulação do processo erosivo in situ, a segunda fase foi processo de simulação do processo carioso nos substratos dentais in situ e a última fase foi a realização do teste de abrasão por meio de escovação in vitro. As análises quantitativas do estudo foram: degrau formado, perfil de desgaste, rugosidade da superfície, volume perdido, número, área e perímetro de túbulos dentinários e quantificação do tecido desmineralizado. A variável qualitativa foi a análise morfológica da superfície, antes e depois do processo de erosão, indução de cárie e abrasão.

\section{Seleção dos dentes}

Foram selecionados dentes humanos extraídos de pacientes que foram submetidos ao tratamento radioterápico e/ou quimioterápico na região de cabeça e pescoço no Hospital das Clínicas de Ribeirão Preto e no Hospital do Câncer de Barretos. Todos os procedimentos para extração dos dentes foram exclusivamente de responsabilidade dos centros oncológicos aqui descritos e realizados por profissionais habilitados para tratar pacientes com necessidades especiais e dentro das necessidades restritas dos pacientes. Estes dentes foram doados pelos pacientes ao Biobanco de Dentes da Faculdade de Odontologia de Ribeirão Preto (FORP) e foram entregues aos pesquisadores somente após a 
assinatura do termo de doação. Enquanto em ambiente hospitalar, os dentes foram armazenados em soro fisiológico, à temperatura ambiente.

Os dentes selecionados foram divididos em grupos de acordo com o tratamento antineoplásico a que foram previamente submetidos. Os grupos foram organizados da seguinte forma: CO - grupo controle: dentes extraídos de pacientes saudáveis ou previamente à realização de qualquer tipo de tratamento antineoplásico; QRT - dentes extraídos de pacientes com tratamento radioterápico e quimioterápico concluído; QTX - dentes extraídos de pacientes com tratamento quimioterápico concluído; RTX- dentes extraídos de pacientes com radioterapia na região de cabeça e pescoço concluída. Os critérios de inclusão e exclusão estão descritos na Tabela 1.

Tabela 1: Tabela de inclusão e exclusão dos dentes para execução do experimento.

\begin{tabular}{l} 
Critérios de inclusão \\
\hline Dentes extraídos de pacientes com \\
diagnóstico de CEC de CCP dos sítios a realização do preparo dos espécimes. \\
primários: cavidade bucal, orofaringe, \\
nasofaringe, hipofaringe e laringe. \\
Os dentes devem estar incluídos dentro \\
do campo de RTX com isodose mínima de \\
$45 G y$. \\
A QTX deve ser baseada em platina. \\
Necessidade de extração estritamente \\
clínica ou perda espontânea dos \\
elementos dentais.
\end{tabular}




\section{Preparo dos espécimes}

Os dentes previamente selecionados para o estudo foram submetidos a limpeza com curetas periodontais e profilaxia com escova de Robinson, pedra pomes e água. Após tais procedimentos, permaneceram armazenados em recipientes contendo soro fisiológico e mantidos em refrigerador à temperatura de aproximadamente $4^{\circ} \mathrm{C}$, até o início da confecção dos espécimes. Os dentes foram inicialmente fixados com cera pegajosa em lâminas de acrílico plexiglass e seccionados na junção amelocementária, com disco diamantado (\#7015, KG Sorensen, Barueri/SP, Brasil) sob refrigeração e auxílio da máquina de corte (Miniton, Struers A/S, DK-2610, Copenhagen, Dinamarca) separando a coroa da raiz. As raízes foram seccionadas utilizando dois discos diamantados separados por um espaçador de $3 \mathrm{~mm}$, sob refrigeração, acoplados em uma máquina de corte. Os discos de dentina obtidos foram novamente fixados e cortados transversalmente com disco único.

Os espécimes foram planificados e polidos com lixas de carbeto de silício de granulação \#1200 (Norton/Saint-Gobain Abrasivos Ltda., São Paulo/SP, Brasil) em politriz (Arotec APL-4, Arotec Indústria e Comércio, São Paulo/SP, Brasil), em baixa velocidade, para obter uma superfície plana e livre de cemento, até atingir a dimensão de $4 \times 3 \times 3 \mathrm{~mm}$ (a superfície a ser empregada no estudo foi a dentina externa da raiz). O polimento dos espécimes foi feito com disco de feltro e suspensão de alumina 0,3 e 0,05 $\mu \mathrm{m}$ (Arotec Indústria e Comércio, São Paulo/SP, Brasil). Ao final do polimento, os fragmentos foram imersos em água deionizada sob ação do ultrassom (Ultrasonic Cleaner $\mathrm{T}$, Odontobrás Indústria e Comercio, Ribeirão Preto/SP, Brasil) por 10 minutos para lavagem e remoção de resíduos.

Visando a homogeneização da distribuição inicial das amostras entre os grupos, foi realizada a microdureza inicial dos fragmentos utilizando microdurômetro (Shimadzu HMV-2000, Kyoto, Japão) com penetrador piramidal tipo Knoop, acoplado ao software do próprio equipamento para análise de imagem, carga estática de $25 \mathrm{gf}$ e tempo de 10 segundos. Os fragmentos foram fixados em lâminas de acrílico plexiglass com auxílio de um paralelômetro e foram realizadas três endentações na superfície separadas entre si por uma 
distância de $200 \mu \mathrm{m}$. Os valores obtidos foram calculados e convertidos por meio de software do próprio equipamento. Ao final desta etapa, os fragmentos que apresentaram microdureza de superfície $20 \%$ acima ou $20 \%$ abaixo da média geral foram descartados. Além disso, previamente à análise de microdureza todos os espécimes foram avaliados no microscópio confocal a laser (LEXT OLS4000, Olympus) para que as amostras que apresentassem trincas, fissuras e anomalias de estrutura fossem excluídas do estudo.

Os fragmentos destinados às fases in situ foram esterilizados em autoclave (Nogueira, 2010) e em seguida foi realizada a sua restauração com resina composta fotopolimerizável (Filtek ${ }^{\mathrm{TM}}$ Z350, 3M ESPE, USA), deixando metade da superfície exposta (área experimental) e a outra metade recoberta por resina composta (área de referência) com o objetivo de proteger a área de referência da exposição à erosão e indução de cárie; na lateral dos fragmentos foi realizada uma marcação para diferenciação das duas áreas.

Os fragmentos destinados para a fase in vitro foram embutidos em resina baquelite em embutidora automática (Arotec PRE-30A, Arotec S.A. Indústria e Comércio, Cotia/SP, Brasil). Cada cilindro de resina baquelite possuía 4 fragmentos, distribuídos aleatoriamente, sendo um de cada grupo de estudo. Para o isolamento da área controle foi utilizado fita isolante preta (3M do Brasil LTDA, Sumaré, SP), deixando a outra metade dos fragmentos, descoberta (área experimental).

Todos os espécimes foram armazenados em água destilada e sob refrigeração $\left(4^{\circ} \mathrm{C}\right)$ até o início do experimento.

\section{Estudo in situ}

\section{Seleção dos voluntários}

Foram selecionados dez voluntários, de ambos os sexos, residentes em Ribeirão Preto, não vulneráveis, com idade entre 18 e 35 anos, esclarecidos, com disponibilidade de tempo para comparecer à faculdade nos horários previamente agendados. Todos foram orientados sobre a metodologia do 
trabalho, seus riscos e benefícios, e assinaram o "Termo de Consentimento Livre e Esclarecido" concordando em participar e colaborar com a execução do trabalho. Previamente ao inicio da execução do experimento, os voluntários foram submetidos à anamnese e exame clínico. Foram excluídos: grávidas; lactantes; fumantes; pessoas que apresentavam doenças sistêmicas; que utilizavam medicamentos que alteram o fluxo salivar ou voluntários que já foram previamente submetidos à quimioterapia ou radioterapia.

Cada voluntário selecionado teve sua arcada superior moldada com hidrocolóide irreversível (Alginato Hydrogum 5 - Zhermack, BadiaPolesine, Rovigo, Itália). O molde obtido foi vazado com Gesso Especial Durone Tipo IV (Dentsply Indústria e Comércio Ltda., Petrópolis/RJ, Brasil) e com base em Gesso Pedra (Herodent Tipo III (Herodent, Vigodent S/A Ind. Com., Rio de Janeiro/RJ, Brasil) obtendo-se assim o modelo de trabalho para a confecção do dispositivo intrabucal superior, o qual foi confeccionado com resina acrílica autopolimerizável (Jet, Artigos Odontológicos Clássico Ltda., São Paulo/SP, Brasil). Os dispositivos foram ajustados com broca maxicut de tungstênio e polidos com lixa d'água \#600 (Norton/Saint-Gobain Abrasivos Ltda., São Paulo/SP, Brasil), pasta de pedra-pomes e branco de Espanha. Após o polimento, foram preparados nichos de superfície para a fixação dos fragmentos de dentina, os quais foram dispostos de forma aleatória na placa.

Foi realizada a calibração dos voluntários quanto à higienização do dispositivo e da cavidade bucal, além disso, foi padronizada a utilização da escova dental (Colgate Professional Lab Series, Colgate Palmolive Industrial LTDA), fio dental (Colgate Total, Colgate Palmolive Industrial LTDA®) e dentifrício fluoretado (Colgate Total 12 Professional Clean, Colgate Palmolive Industrial LTDA $囚$ ), fornecidos pela pesquisadora. Após este período foi verificada a adaptação intra-bucal dos dispositivos e os ajustes necessários foram realizados. 


\section{$\underline{1^{\text {a }} \text { fase- Indução da erosão in situ }}$}

Foram utilizados 40 fragmentos de dentina radicular, aleatoriamente distribuídos entre 14 voluntários, os quais receberam fragmentos submetidos à radioterapia (RTX), quimioterapia (QTX), quimioradioterapia (QRT) e dentes que não foram submetidos a nenhum tipo de tratamento, controle (CO). Os fragmentos foram fixados $0,5 \mathrm{~mm}$ abaixo da superfície da resina.

Os voluntários usaram os dispositivos intra-bucais por 24 horas antes de iniciar os desafios para que houvesse a formação da película adquirida e para que se adaptassem ao dispositivo, sendo realizados os ajustes necessários nesse período. Para o desafio erosivo, os voluntários foram calibrados para realizar a imersão do dispositivo intrabucal em $50 \mathrm{~mL}$ de refrigerante à base de Cola $(\mathrm{pH} 2,6)$ em copo dosador fornecido pelos pesquisadores sob agitação por 20 segundos, 6 vezes ao dia, durante 6 dias, sendo a solução trocada a cada desafio. Os voluntários foram orientados a escoar o refrigerante e aguardar 1 minuto após o desafio para então fazer a imersão do dispositivo em água, no copo dosador, sob agitação por 20 segundos. A seguir, o dispositivo era recolocado na cavidade bucal (Figura 1). Os voluntários podiam realizar a higienização da porção do dispositivo que estava em contato com o palato apenas com a escova dental, sem utilizar o dentifrício.
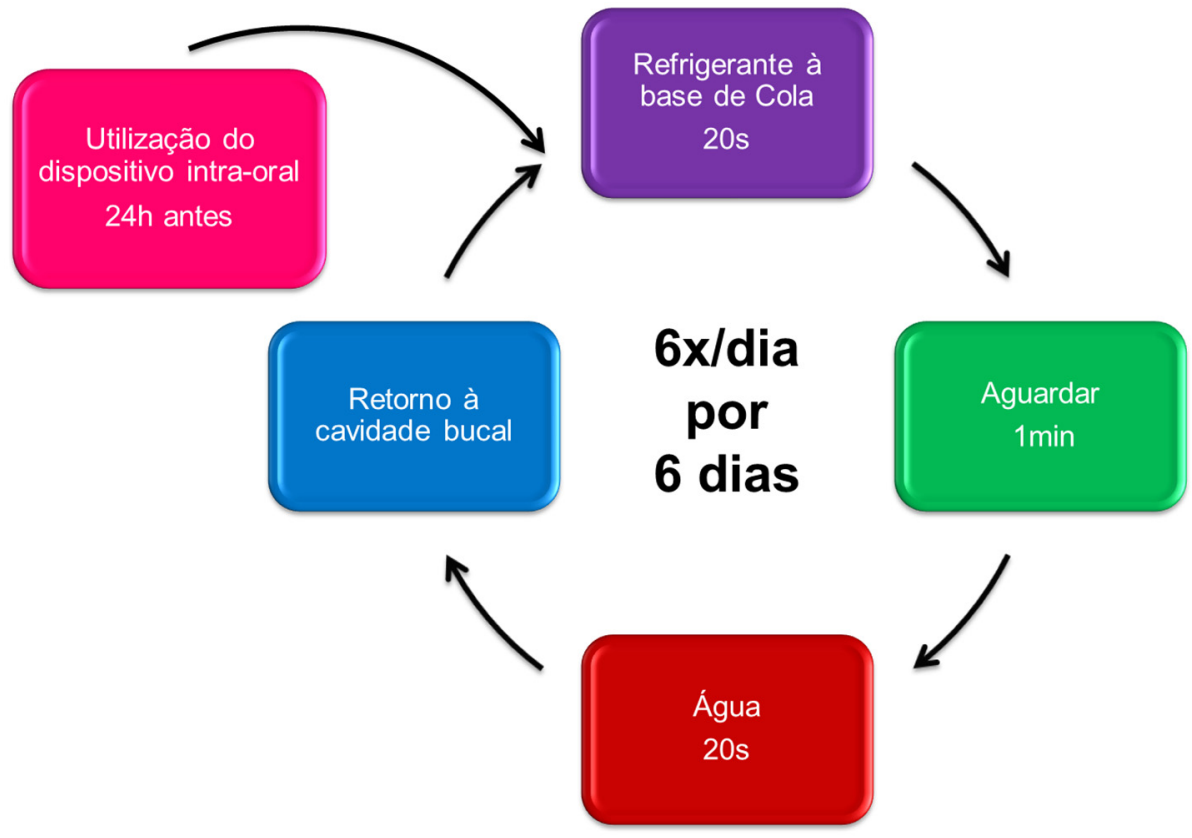

Figura 1. Fluxograma dos procedimentos experimentais para indução de erosão in situ. 
Após os 7 dias, os dispositivos foram devolvidos e os fragmentos foram coletados para análise topográfica por meio de microscopia confocal a laser (CLSM), avaliando o degrau formado; perfil de desgaste; rugosidade superficial; volume perdido; número, área e perímetro dos túbulos dentinários e morfologia da estrutura dental. Foi realizada também a tomografia de coerência óptica (OCT) para quantificar do tecido desmineralizado (Figura 2). 

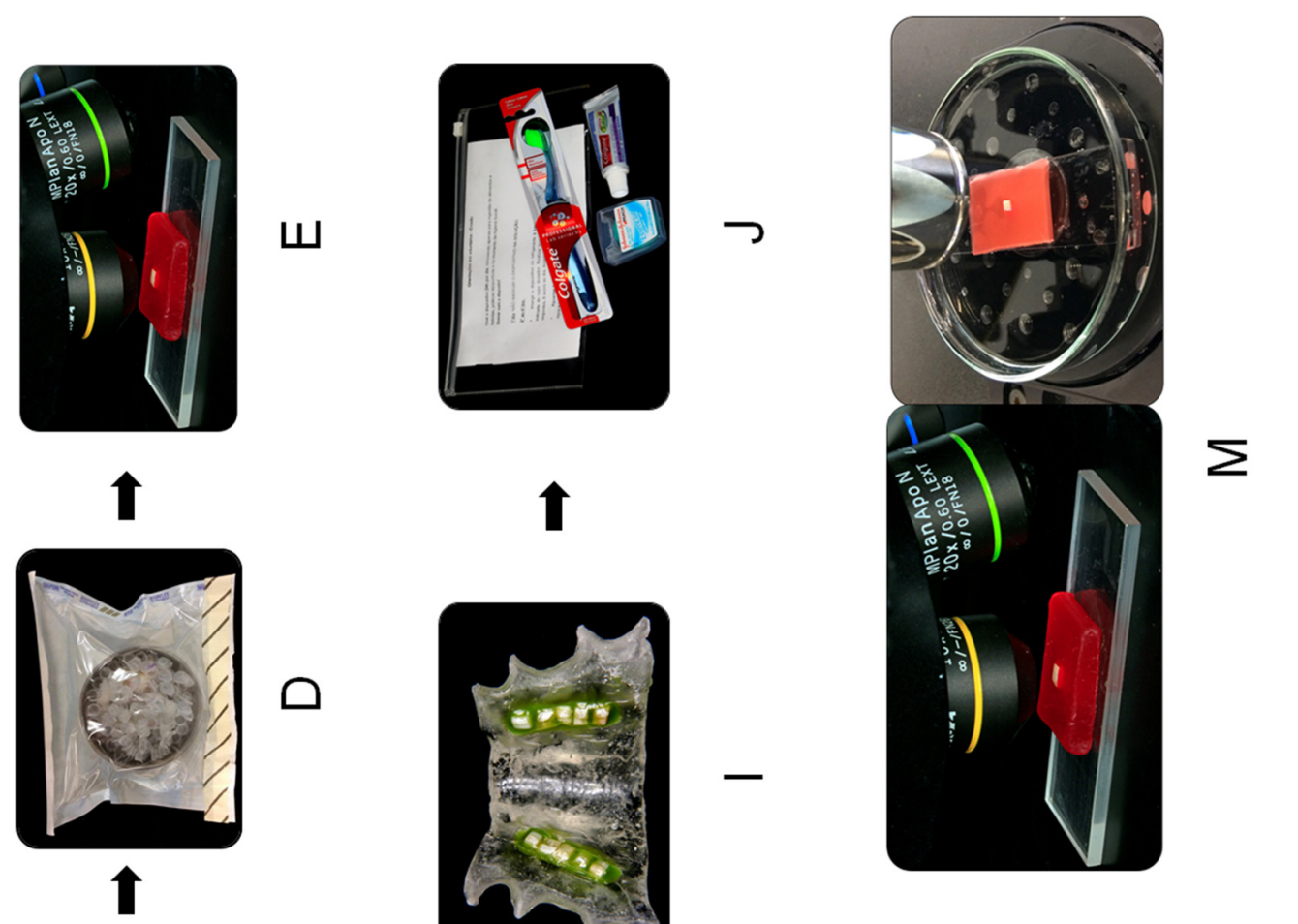

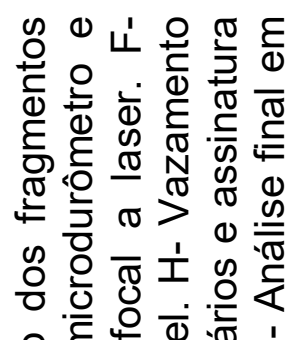
을 늘 U্ 웡 क 응 웡

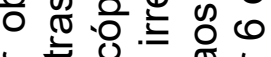

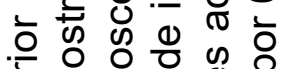
을 은 응 \&

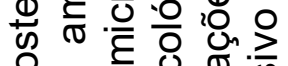
음

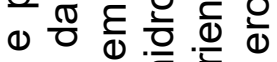

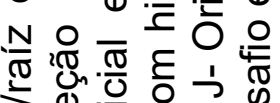

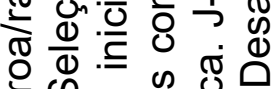
잉 ฏ

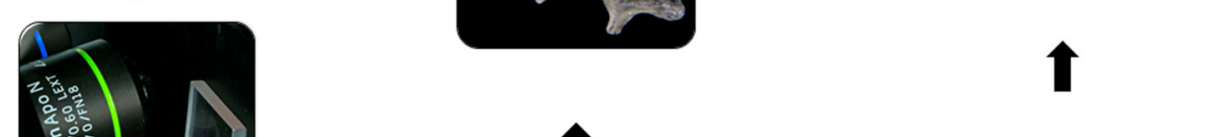
U่

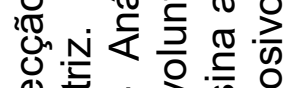
๙ < 으 म $\because \frac{\varepsilon}{0} \stackrel{ }{\complement} \frac{1}{\Phi}$

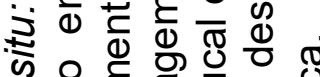

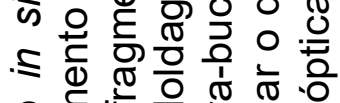

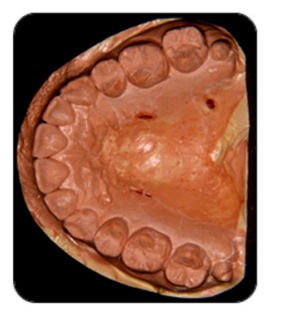

I
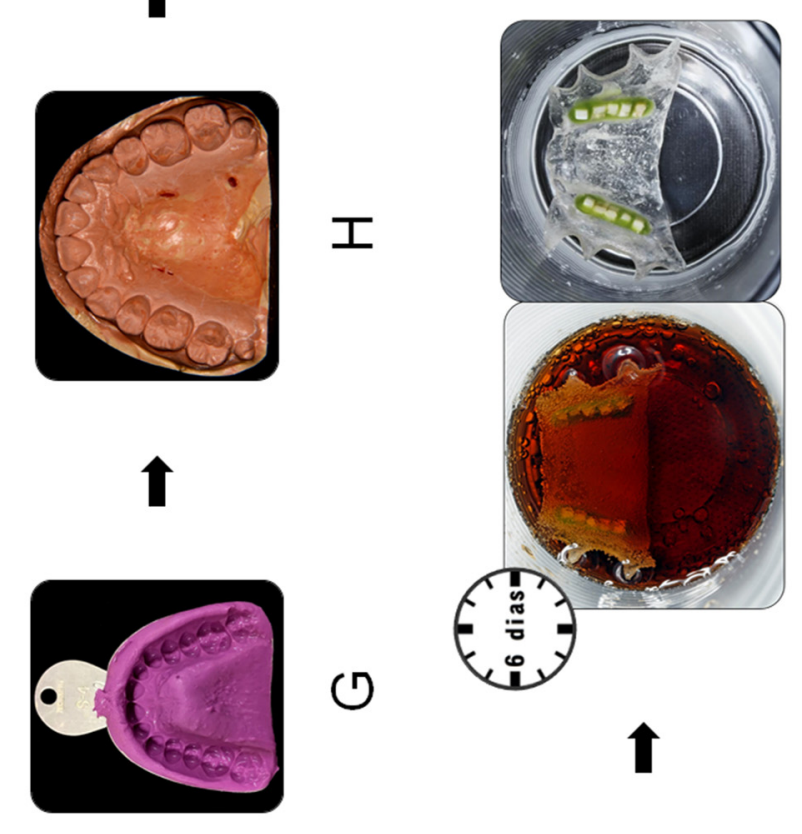

0

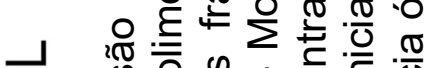

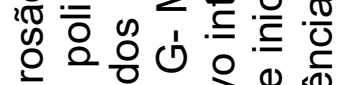
ब 0 ( 중

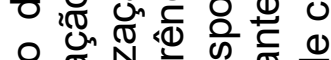
20

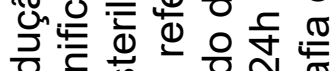

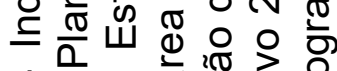

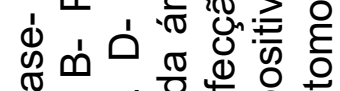
๘ ๘

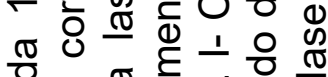
ช $\sigma \frac{\varepsilon}{\sigma} \dot{0} 0 \frac{0}{\sigma}$

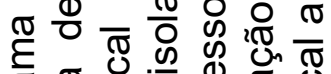
స్ $\sigma$ U.

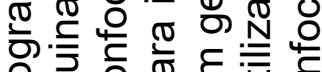

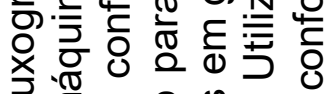

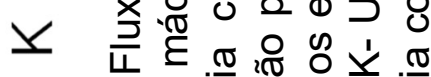

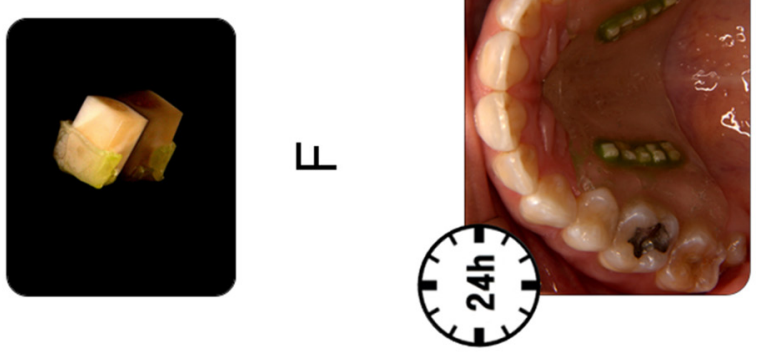

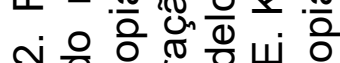

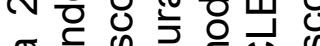

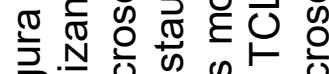

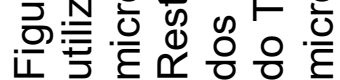




\section{$\underline{2^{\mathrm{a}} \text { fase - Indução de lesão de cárie in situ }}$}

Nessa fase, também foram utilizados 40 fragmentos de dentina radicular aleatoriamente distribuídos entre 10 voluntários, os quais receberam fragmentos submetidos à radioterapia (RTX), quimioterapia (QTX), quimioradioterapia (QRT) e dentes que não foram submetidos a nenhum tipo de tratamento, controle (CO). Os fragmentos foram fixados $2,0 \mathrm{~mm}$ abaixo da superfície da resina e cobertos por um tule com a finalidade de permitir o acúmulo de biofilme sobre eles.

Os voluntários usaram os dispositivos intrabucais por 24 horas antes de iniciar os desafios para que houvesse a formação da película adquirida e para que se adaptassem ao dispositivo, sendo realizados os ajustes necessários nesse período. Após esse período, o dispositivo foi utilizado por 14 dias, e os voluntários foram calibrados quanto a aplicação da solução de sacarose $20 \%$ em cada fragmento 6 vezes ao dia em horários pré-estabelecidos (Pecharki et al., 2005; Rodrigues et al., 2006). Os voluntários também foram orientados a aguardar 1 minutos após o desafio para só então retornar o dispositivo à cavidade bucal (Figura 3). Eles podiam realizar a higienização da porção do dispositivo que ficava em contato com o palato, apenas com escova dental, sem utilizar dentifrício.

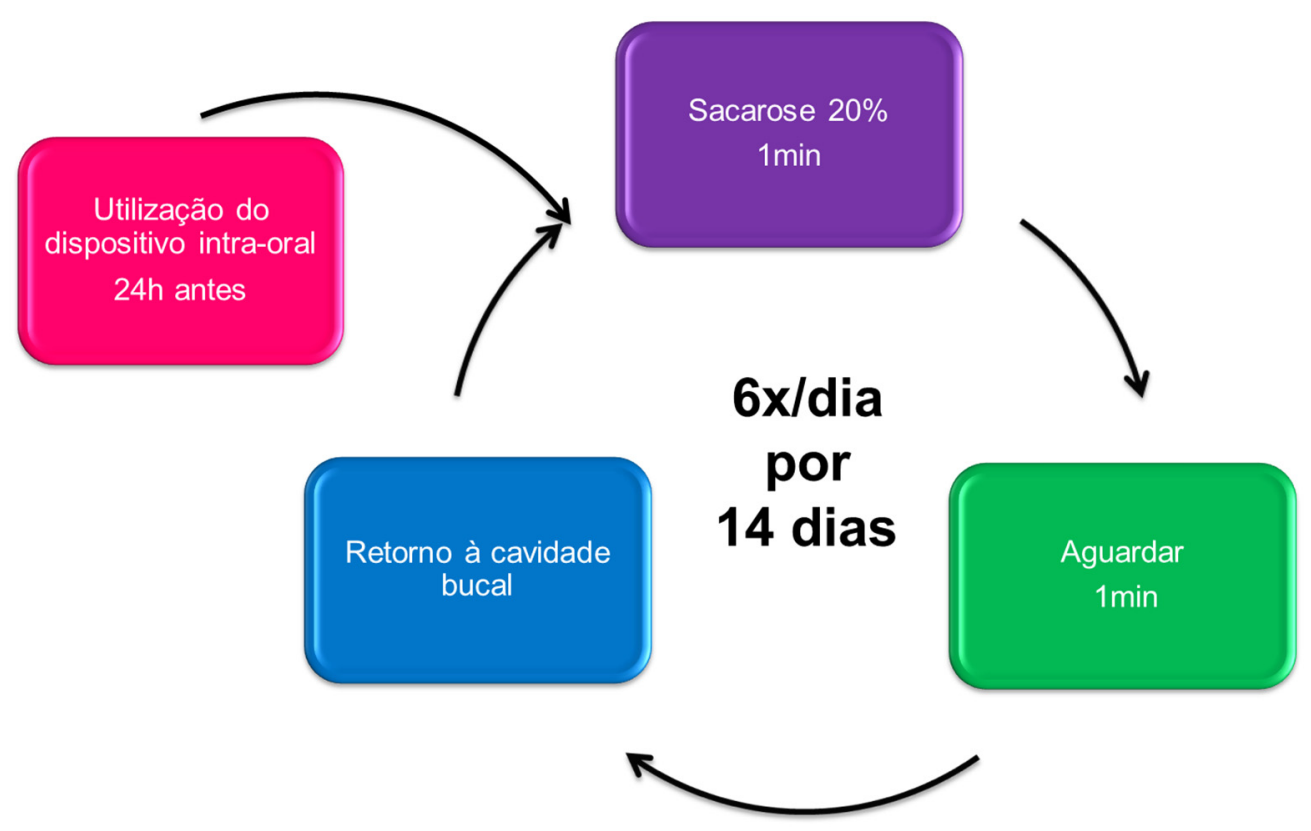

Figura 3. Fluxograma dos procedimentos experimentais para indução de cárie in situ. 
Após o $14^{\circ}$ dia de desafio cariogênico o biofilme foi removido e os fragmentos foram coletados para análise topográfica por meio de CLSM, avaliando o degrau formado; perfil de desgaste; rugosidade superficial; volume perdido; número, área e perímetro dos túbulos dentinários e morfologia da estrutura dental. Foi realizada também a tomografia de coerência óptica para quantificar o tecido desmineralizado (Figura 4). 


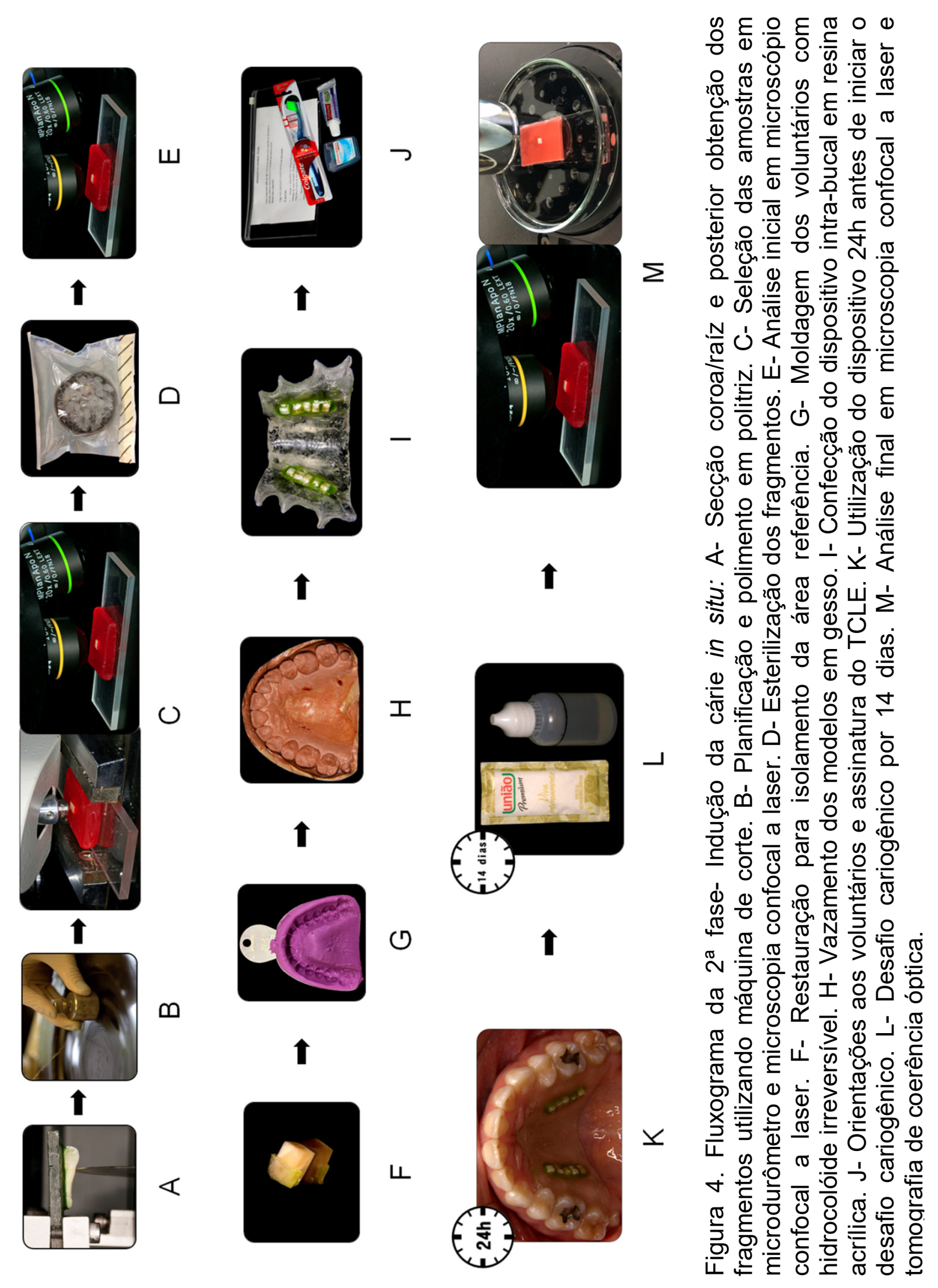




\section{$\underline{3^{a} \text { fase - Ensaio de abrasão in vitro }}$}

Para a avaliação da abrasão, foram utilizados 40 fragmentos de dentina radicular, submetidos à radioterapia (RTX), quimioterapia (QTX), quimioradioterapia (QRT) e dentes que não foram submetidos a nenhum tipo de tratamento, controle (CO). A abrasão dentinária foi realizada através de uma máquina de escovação (Biopdi, São Carlos, SP, Brasil) e para leitura dos resultados, foi empregado o microscópio confocal a laser. Para o ensaio, foi utilizada uma escova ultramacia (Colgate Professional Lab Series, Colgate Palmolive Industrial LTDA) por bloco de espécimes com seus cabos removidos para proporcionar o encaixe das cabeças das escovas nas sapatas da máquina de escovação.

As unidades experimentais foram alinhadas de modo que as cabeças deslocassem paralelamente às suas superfícies, percorrendo um curso corresponde a 3,8 centímetros em um movimento de vaivém horizontal. Foram escovadas dez amostras simultaneamente, cada cabeça de escovação carregada com um peso de $200 \mathrm{~g}$ e percorrendo horizontalmente por $20 \mathrm{~mm}$, a uma velocidade de 4,5 movimentos por segundo.

Os espécimes foram escovados num total de 10.000 ciclos, o que seria o equivalente a um ano de escovação (Goldstein \& Lerner, 1991; Yuan, 2017). Um volume de $10 \mathrm{~g}$ de dentifrício (Colgate Total 12 Professional Clean, Colgate Palmolive Industrial LTDA®) foi misturado em $20 \mathrm{ml}$ de água destilada (proporção 1:2, em peso) e posteriormente vertido com seringa plástica $(10 \mathrm{ml}$ de solução) igualmente em cada cuba sobre os fragmentos em uma frequência de $0,4 \mathrm{ml}$ em intervalos de dois minutos.

Após o término do teste, os corpos de prova foram removidos, lavados em água corrente e limpos por ultrassom e água deionizada durante 10 minutos. Os fragmentos foram levados ao microscópio confocal a laser para serem realizadas as análises de perfil de desgaste; degrau formado; rugosidade superficial e volume perdido (Figura 5 ) 


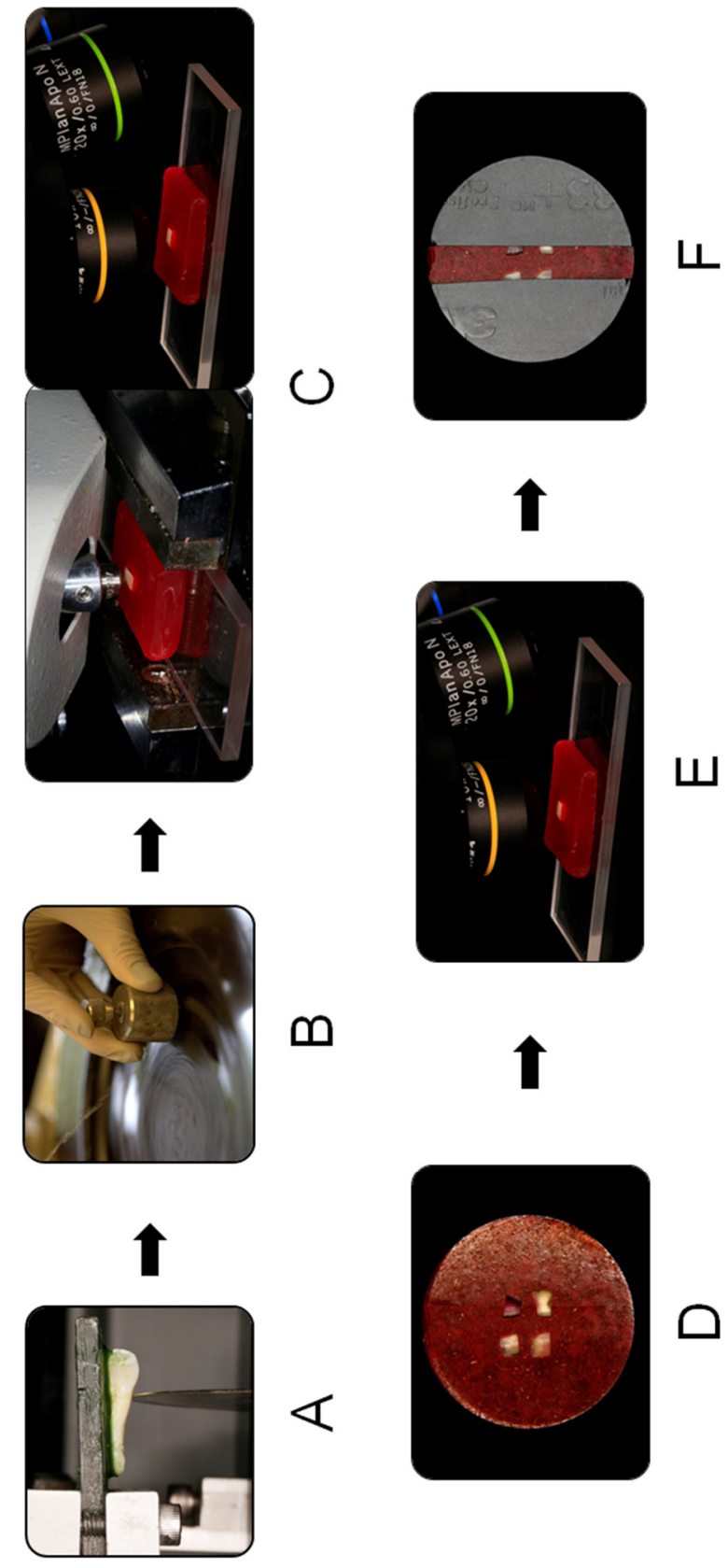

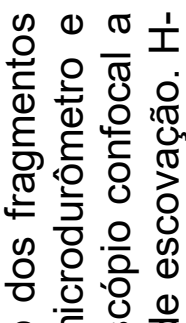

○ ह

i⿱

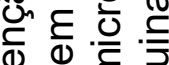

थ $\frac{\nabla}{\sigma}$

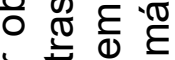

은 क्ष $\frac{\pi}{0} \frac{\varepsilon}{0}$

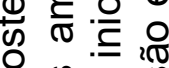

舟

(1)

$N \circ \stackrel{\pi}{\frac{\pi}{C}}$

전

I $\quad \frac{\Phi}{\Phi} \dot{0}$

ठ ळ

○่言

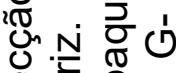

创

ゆ

文这.

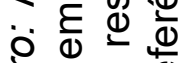

인 $\frac{\varepsilon}{0}$

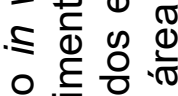

诜

으음응

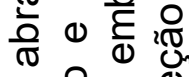

(1)

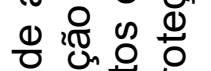

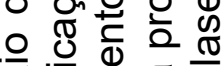

쥰

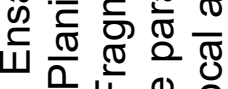

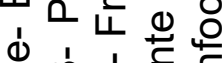

め ๘ ๓ ชర

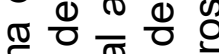

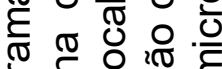
는 음 응 छ Х. 프 เ ช 든

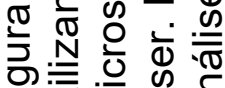
은 吾 
Após o término de cada experimento, a resina composta (ensaios in situ) ou fita isolante (ensaio in vitro) que protegia a metade da superfície foi removida e os espécimes foram levados para análise em CLSM e/ou OCT para a captura e análise das imagens e obtenção dos dados. Para cada análise foram feitas imagens específicas com aumento apropriado para a análise a ser realizada.

As análises realizadas para o desafio erosivo (primeira fase) e indução de cárie (segunda fase) foram: perfil de desgaste; degrau formado; volume perdido; rugosidade superficial; número, área e perímetro dos túbulos dentinários; morfologia da estrutura dental e quantificação do tecido desmineralizado. As análises realizadas para o ensaio de abrasão (terceira fase) foram: perfil de desgaste; degrau formado; volume perdido e rugosidade da superfície.

Perfil de desgaste e degrau formado

Os espécimes foram posicionados na base do microscópio confocal a laser (LEXT OLS4000, Olympus), e com auxilio de objetivas de 10x de aumento foram realizadas imagens com $216 x$ de aumento na região central de cada espécime. A imagem englobava uma região de referência de dentina, não exposta (1/3), e uma região de dentina exposta (2/3). O perfil de desgaste (Figura 6) e degrau formado (Figura 7) da área não-exposta/ área exposta foram determinados a partir da área de referência. Ao todo foram realizadas 10 leituras de cada espécime para cada uma das diferentes análises. Os dados foram obtidos por meio do software específico (Olympus, LEXT OLS4000) em micrometros $(\mu \mathrm{m})$. 


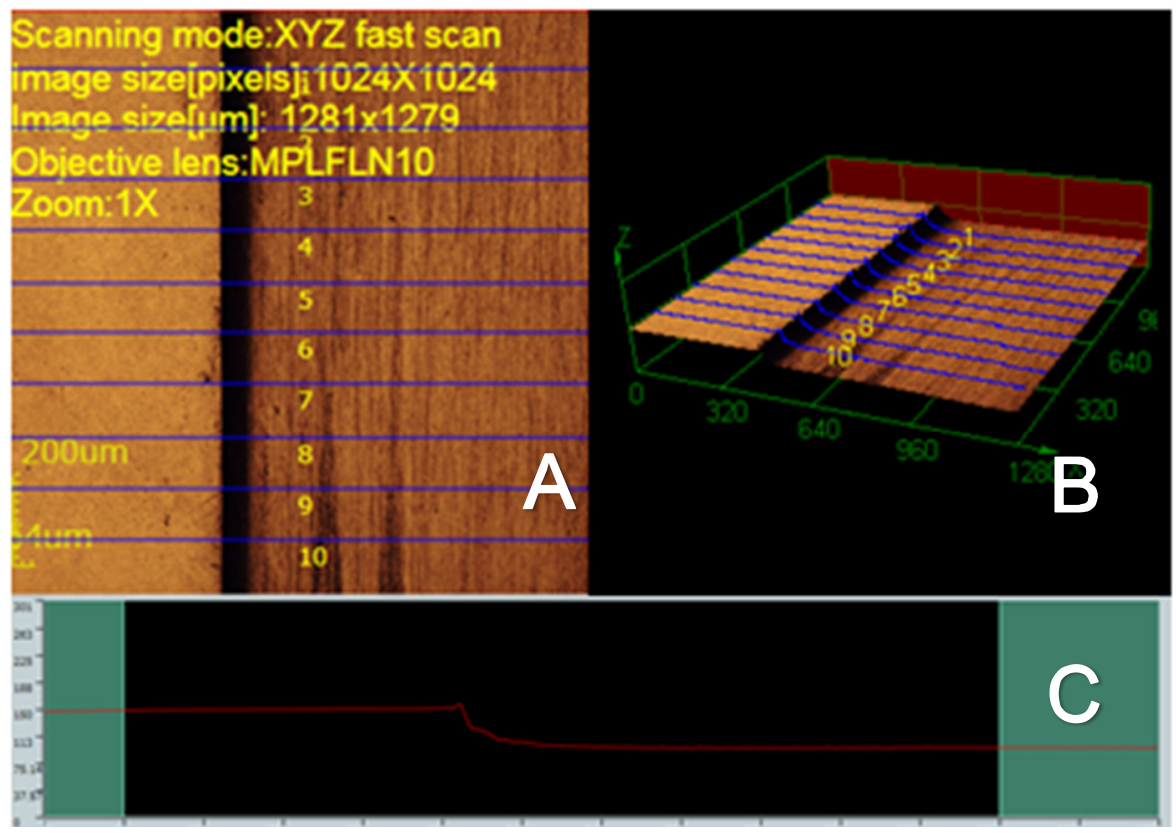

Figura 6. Mensuração do perfil de desgaste $(\mu \mathrm{m})$ : A-.Imagem 2D, BImagem 3D, C- Gráfico representativo da mensuração.

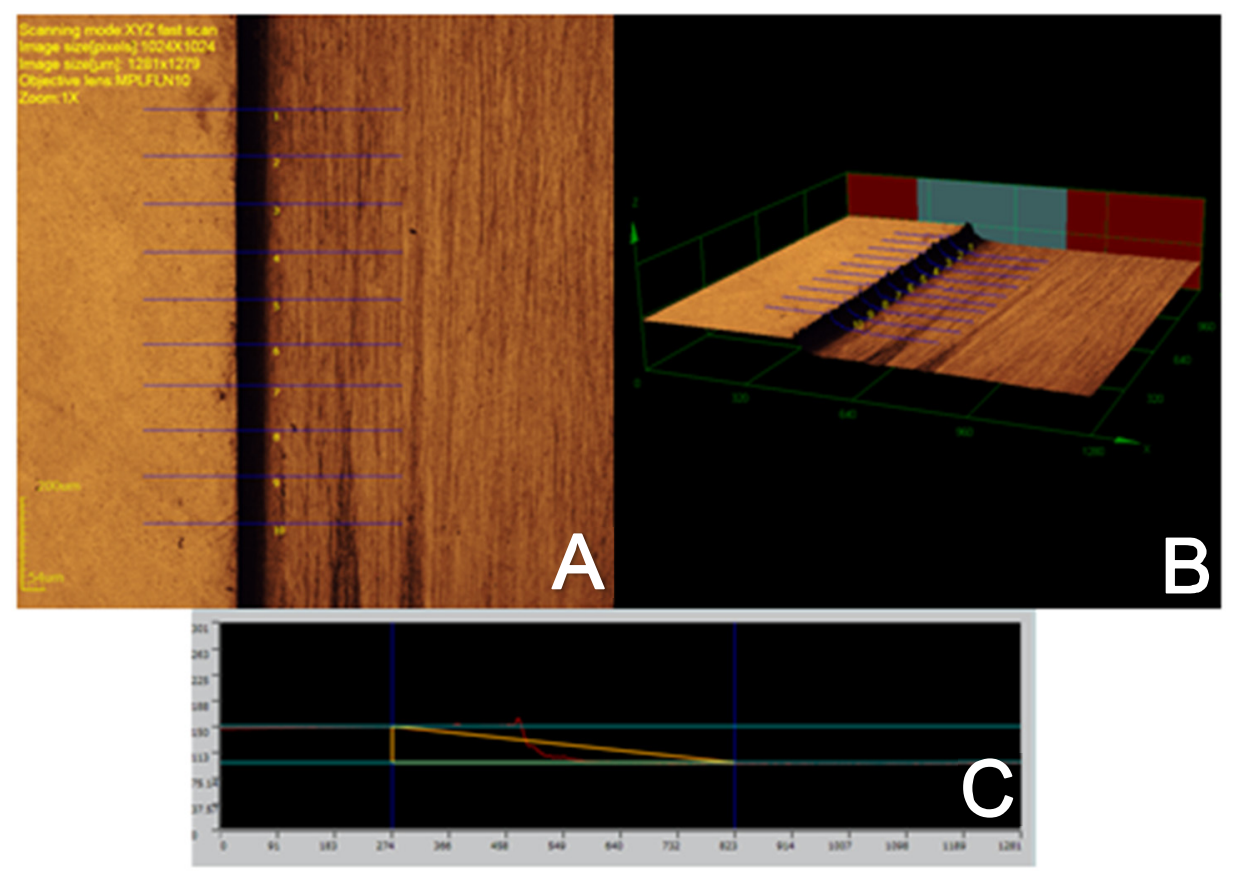

Figura 7. Mensuração do degrau formado $(\mu \mathrm{m})$ : A-.Imagem 2D, BImagem 3D, C- Gráfico representativo da mensuração. 


\section{Volume perdido}

Para realização da medição do volume perdido foi traçado um plano englobando uma região referência de dentina não exposta (1/3) e um plano englobando a região de dentina exposta $(2 / 3)$ de forma que toda a estrutura perdida abaixo do plano de referência foi calculada em $\mu \mathrm{m}^{3}$ (Figura 8). Esta análise determinou o quanto de tecido mineralizado foi perdido durante os processos DES/RE ou abrasivos.

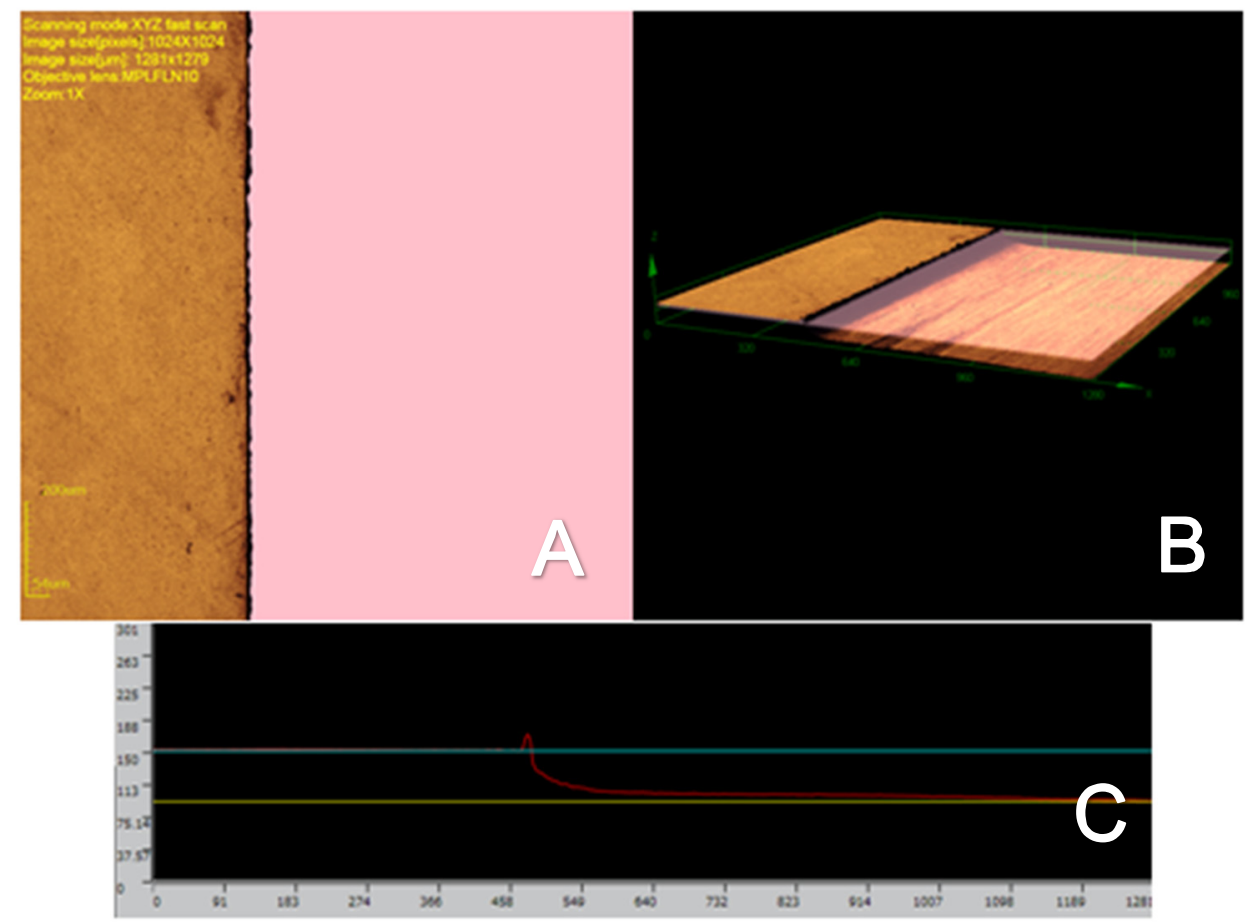

Figura 8. Mensuração do volume perdido $\left(\mu \mathrm{m}^{3}\right)$ : A-.Imagem 2D, BImagem 3D, C- Gráfico representativo da mensuração.

\section{Rugosidade de superfície}

Imagens com 216x de aumento foram realizadas para mensurar a rugosidade da amostra inicial e final, em uma região central padronizada da dentina. Em cada imagem foi calculada a rugosidade superficial - Sa $(\mu \mathrm{m}) \mathrm{da}$ área não exposta (referência) e da área exposta (experimental) por meio da seleção da área de interesse, utilizando ROI (Figura 9). 

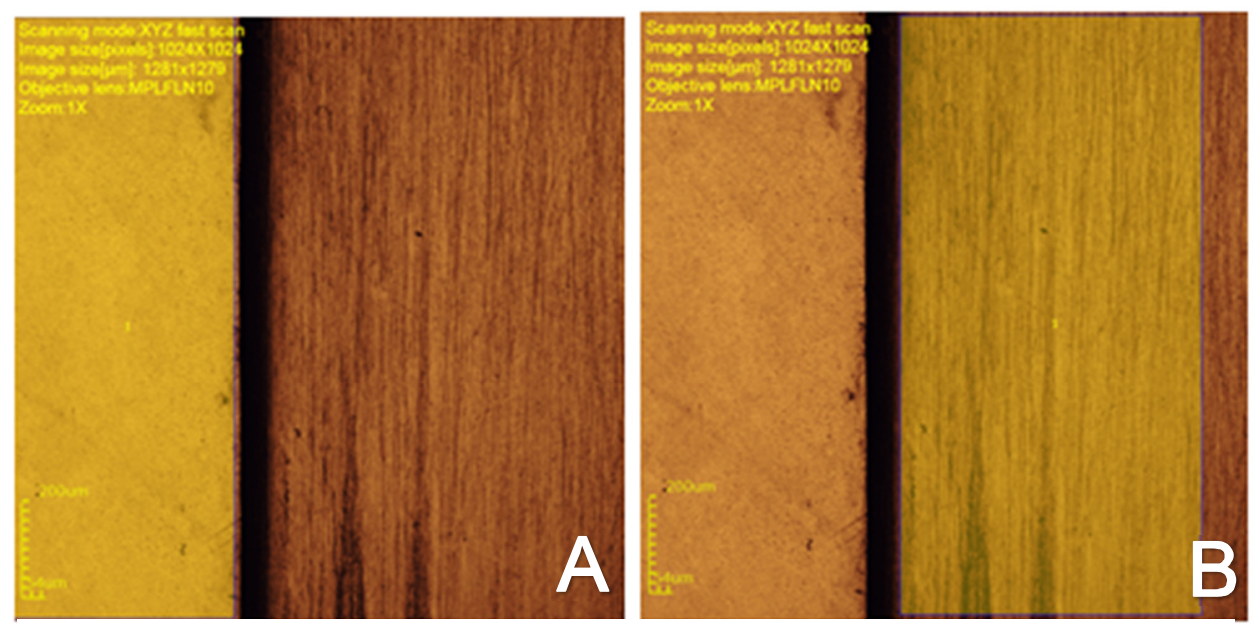

Figura 9. Mensuração da rugosidade superficial $(\mu \mathrm{m})$ : A-.Imagem 2D com ROI da área de referência, B- Imagem 2D com ROI da área exposta.

\section{Número, área e perímetro dos túbulos dentinários}

As análises foram baseadas na diferença do número, área e perímetro do lúmen dos túbulos dentinários radiculares. Para isso foram obtidas imagens de 2131x de aumento da amostra inicial em uma região central padronizada da dentina e após o desafio. Todas as imagens foram realizadas na mesma região antes e depois. Por meio do software OLS 4000, foram localizados os túbulos em cada imagem e realizado o cálculo de número de túbulos, a área $\left(\mu m^{2}\right)$ e 0 perímetro $(\mu \mathrm{m})$ do lúmen dos túbulos (Figura 10).

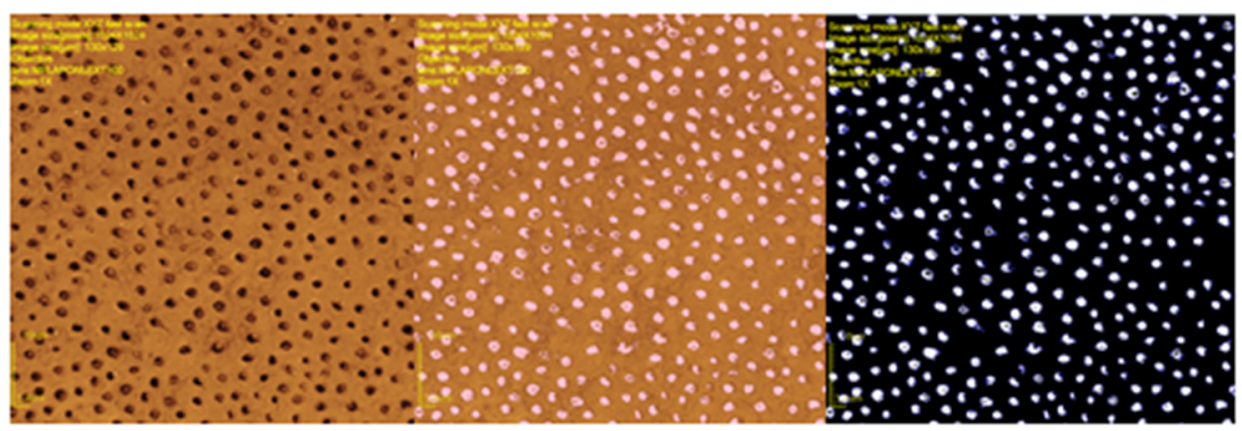

Figura 10. Mensuração do número, área e perímetro dos túbulos dentinários. 
Quantificação do tecido desmineralizado

Para esta análise, foram adquiridas imagens de seção transversal dos fragmentos por um equipamento de tomografia de coerência óptica (OCT) modelo OCS1300ss (Thorlabs, Inc., New Jersey, EUA), cujas principais características são: (i) fonte iluminação na região do infravermelho centralizada em 1300nm e largura de banda de $100 \mathrm{~nm}$; (ii) taxa máxima de aquisição de 16 kHz; (iii) lente de aquisição de dados de 10x; (iv) resolução axial e lateral de 12 e $25 \mu \mathrm{m}$, respectivamente.

A tomografia por coerência óptica é uma técnica relativamente nova, usada para a obtenção imagens de matérias e tecidos biológicos com resolução micrométrica. Seu princípio de funcionamento é similar ao do ultrassom, com a diferença de que se usa luz ao invés de ondas sonoras. A composição da imagem da estrutura interna da amostra é dada por meio da luz retroespalhada que atinge o detector.

Assim, quando a luz incide sobre a amostra, ela é atenuada com o aumento da profundidade. A maior ou menor atenuação da luz dependerá de quanto o material absorve e/ou espalha; de forma que a passagem de luz por uma amostra pode ser avaliada medindo a transmitância e refletância da mesma. Numa imagem de OCT a quantidade de luz retroespalhada a certa profundidade da amostra está intimamente relacionada com o brilho da imagem.

Os componentes minerais da dentina atuam como elementos espalhadores de luz acrescentado brilho à imagem de OCT. Assim, a perda mineral dentinária cria descontinuidades teciduais que se refletem na perda de intensidade dos pixels constituintes das imagens. Isso permite a detecção de mínimas alterações no brilho das amostras. A quantificação da desmineralização dos fragmentos expostos ao desafio erosivo ou carioso foi realizada por meio da mensuração do brilho das imagens de OCT.

Para a mensuração do brilho das imagens de OCT, foi realizada a seleção de uma área padrão de 15000 pixels $^{2}$ tanto na área não exposta (referência) como da área exposta. A quantificação do tecido desmineralizado dada pelo brilho foi feita por meio do software ZEN 2.3 blue edition, Carl Zeiss 
Microscopy GmbH, 2011.

As imagens em escala de cinza permitiram a observação de 256 níveis de intensidades diferentes variando entre intensidade zero (0 ou preto) e intensidade máxima (255 ou branco)(Figura 11). De cada área selecionada foi medido seu brilho médio, referente à média aritmética da intensidade dos pixels constituintes de cada imagem, obtendo assim o valor referente a quantidade de tecido desmineralizado para cada região.

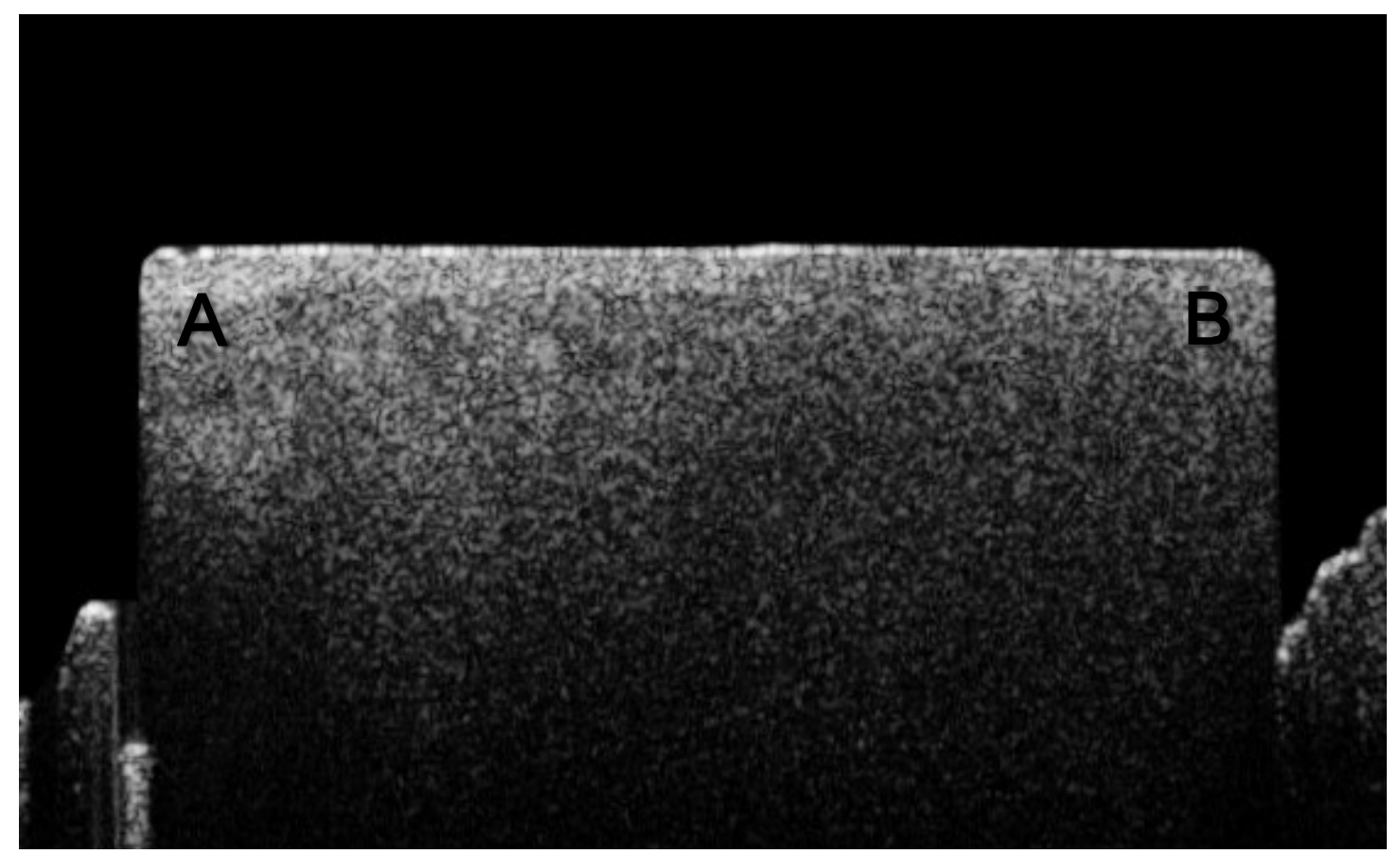

Figura 11. Quantificação do tecido desmineralizado: área não exposta $(A)$, área exposta (B).

\section{Análise dos dados}

Os dados obtidos foram analisados quanto a sua normalidade e homogeneidade. Para os dados fornecidos pelo CLSM, realizou-se análise de variância a 1 critério para os que foram normais e como complementar, o teste de Fisher. Para os que não foram normais empregou-se o teste de KruskalWallis. O nível de significância empregado foi de 5\%. Os dados fornecidos pelo OCT foram analisados pelo teste não-paramétrico de Friedman ( $\alpha=5 \%$ ). 

4. Resultados 



\section{RESULtAdos}

\section{$1^{\text {a }}$ fase- Indução da erosão in situ}

De acordo com os dados obtidos, não foi encontrada diferença estatística significante entre os grupos para as análises de perfil de desgaste, degrau formado e rugosidade $(p>0,05)$, havendo diferença apenas para a análise de volume perdido (Figura 12), na qual, o grupo QRT apresentou o valor mais elevado comparado aos outros. $(p<0,05)$ (Tabela 2$)$.

Tabela 2. Média e desvio padrão dos grupos para perfil de desgaste ( $R v$ em $\mu \mathrm{m}$ ), degrau formado $(\mu \mathrm{m})$, rugosidade (Sa em $\mu \mathrm{m}$ ) e média, desvio padrão e mediana dos grupos para volume perdido $\left(\mu \mathrm{m}^{3}\right)$ para Indução de Erosão.

\begin{tabular}{c|cccc} 
& Perfil de desgaste & Degrau formado & Rugosidade & Volume perdido.10 \\
\hline CO & $1,12 \pm 0,26 \mathrm{a}$ & $6,66 \pm 5,86 \mathrm{~b}$ & $0,57 \pm 0,19 \mathrm{c}$ & $7,32 \pm 9,32(2,65) \mathrm{de}$ \\
\hline QRT & $1,12 \pm 0,42 \mathrm{a}$ & $6,72 \pm 5,51 \mathrm{~b}$ & $0,56 \pm 0,35 \mathrm{c}$ & $15,13 \pm 12,68(11,54) \mathrm{f}$ \\
\hline QTX & $1,13 \pm 0,51 \mathrm{a}$ & $6,75 \pm 6,42 \mathrm{~b}$ & $0,55 \pm 0,21 \mathrm{c}$ & $11,61 \pm 19,10(5,96) \mathrm{de}$ \\
\hline RTX & $1,15 \pm 0,36 \mathrm{a}$ & $6,21 \pm 4,85 \mathrm{~b}$ & $0,49 \pm 0,28 \mathrm{c}$ & $12,56 \pm 13,60(7,10) \mathrm{df}$ \\
\hline
\end{tabular}

*Letras iguais indicam semelhança estatística na mesma coluna para os diferentes grupos.

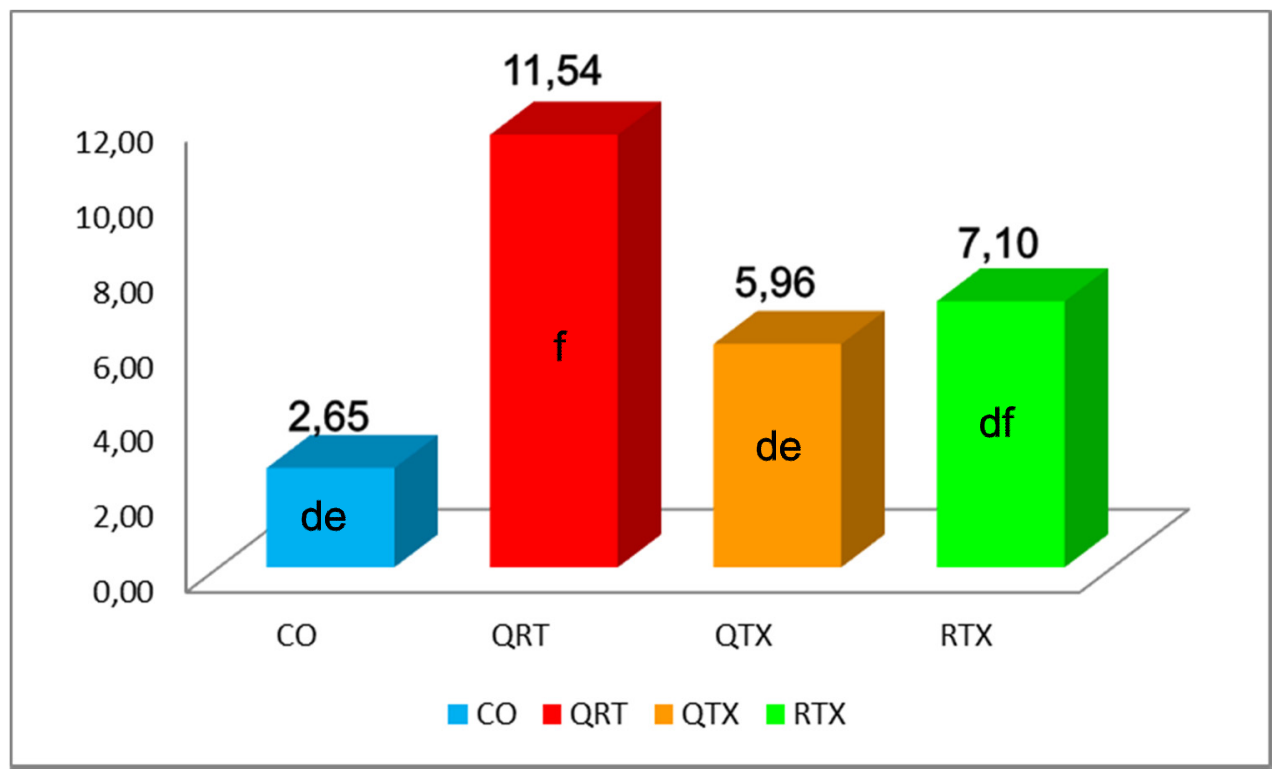

Figura 12. Gráfico representativo da mediana para volume perdido para a fase de Indução de Erosão. 
No número (Figura 13), área (Figura 14) e perímetro (Figura 15) dos túbulos observou-se diferença estatística significante na comparação final-inicial dentro de um mesmo grupo $(p<0,05)$. Não houve diferença significante entre os grupos, contudo o grupo QTX apresentou o maior incremento quanto ao número e perímetro de túbulos $(p>0,05)$.

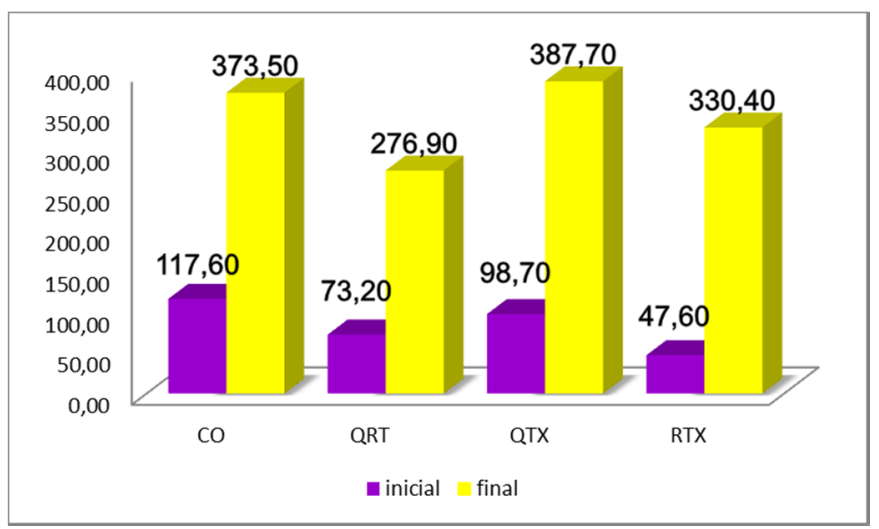

Figura 13. Gráfico representativo da média para número de túbulos para a fase de Indução de Erosão.

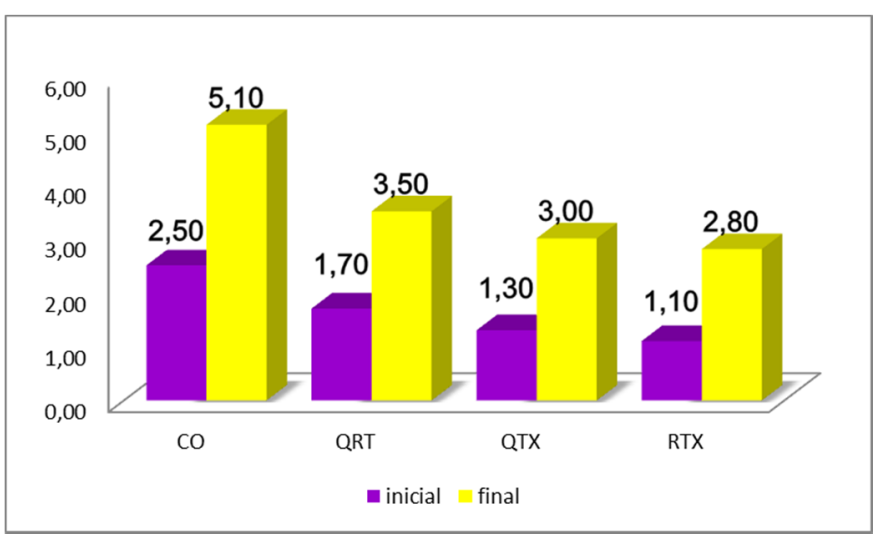

Figura 14. Gráfico representativo da média para área dos túbulos $\left(\mathrm{em} \mu \mathrm{m}^{2}\right)$ para a fase de Indução de Erosão.

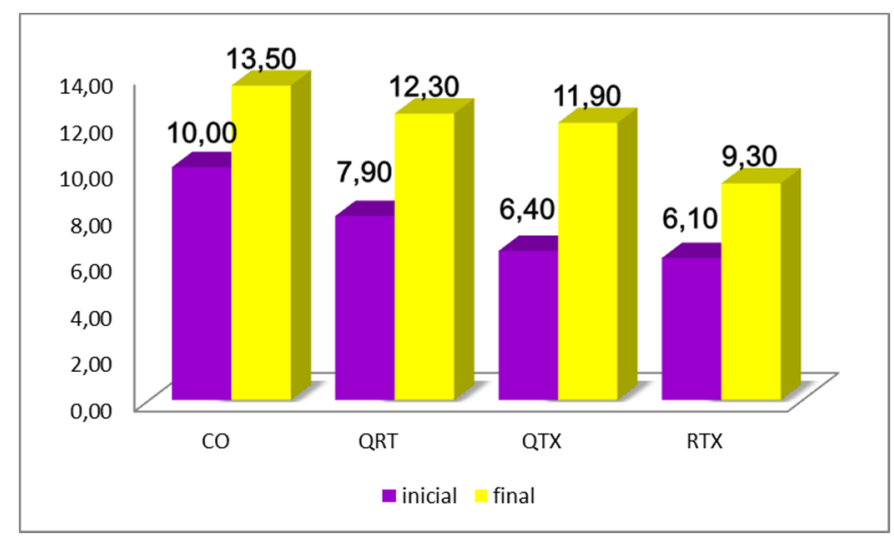

Figura 15. Gráfico representativo da média para perímetro $(\mathrm{em} \mu \mathrm{m})$ dos túbulos para a fase de Indução de Erosão. 
Quanto à quantificação do tecido desmineralizado, os grupos QTX e RTX apresentaram os maiores valores (Figura16), mas não foi encontrada diferença estatística significante entre os grupos $(p>0,05)$ (Tabela 3$)$.

Tabela 3. Média, desvio padrão e mediana dos grupos para quantificação do tecido desmineralizado para Indução de Erosão.

\begin{tabular}{cc}
\hline \multicolumn{2}{c}{$1^{\text {a }}$ Fase -Erosão } \\
\hline CO & $13,43 \pm 17,99(4,64) \mathrm{a}$ \\
\hline QRT & $6,28 \pm 6,83(6,28) \mathrm{a}$ \\
\hline QTX & $11,99 \pm 12,69(9,01) \mathrm{a}$ \\
\hline RTX & $10,67 \pm 10,68(9,25) \mathrm{a}$ \\
\hline
\end{tabular}

*Letras iguais indicam semelhança estatística para os diferentes grupos.

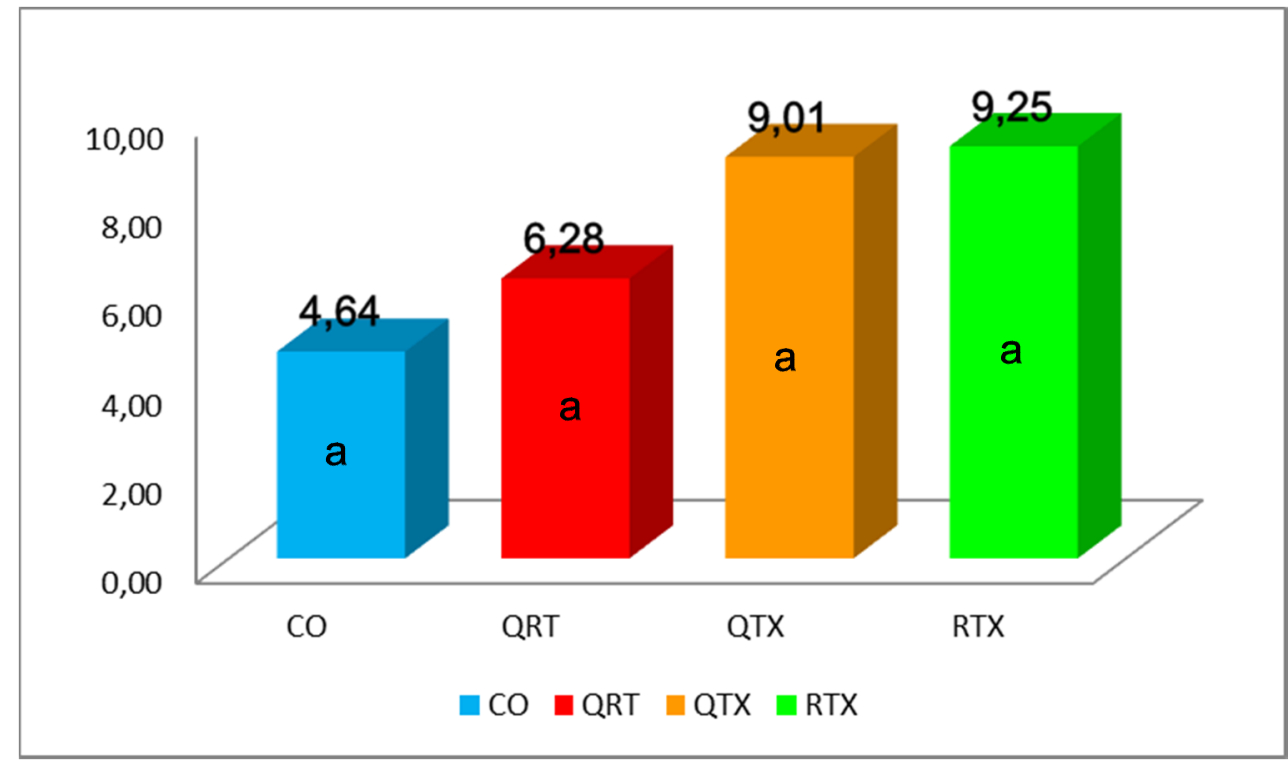

Figura 16. Gráfico representativo da mediana para quantificação do tecido desmineralizado para a fase de Indução de Erosão.

\section{Morfologia de superfície}

As imagens mais representativas obtidas por microscopia confocal a laser para erosão estão apresentadas nas Figuras 17 e 18. Observa-se, na Figura 17, que a área protegida possui tecido dentinário radicular íntegro e na área exposta 
observa-se a formação de um degrau entre a área protegida e a exposta. Notase uma perda de tecido dentinário devido ao desafio erosivo com o refrigerante tipo cola (pH 2,6). O grupo QTX (Figura 17C) apresentou visualmente padrão de desmineralização mais uniforme e com menor intensidade que os demais grupos.

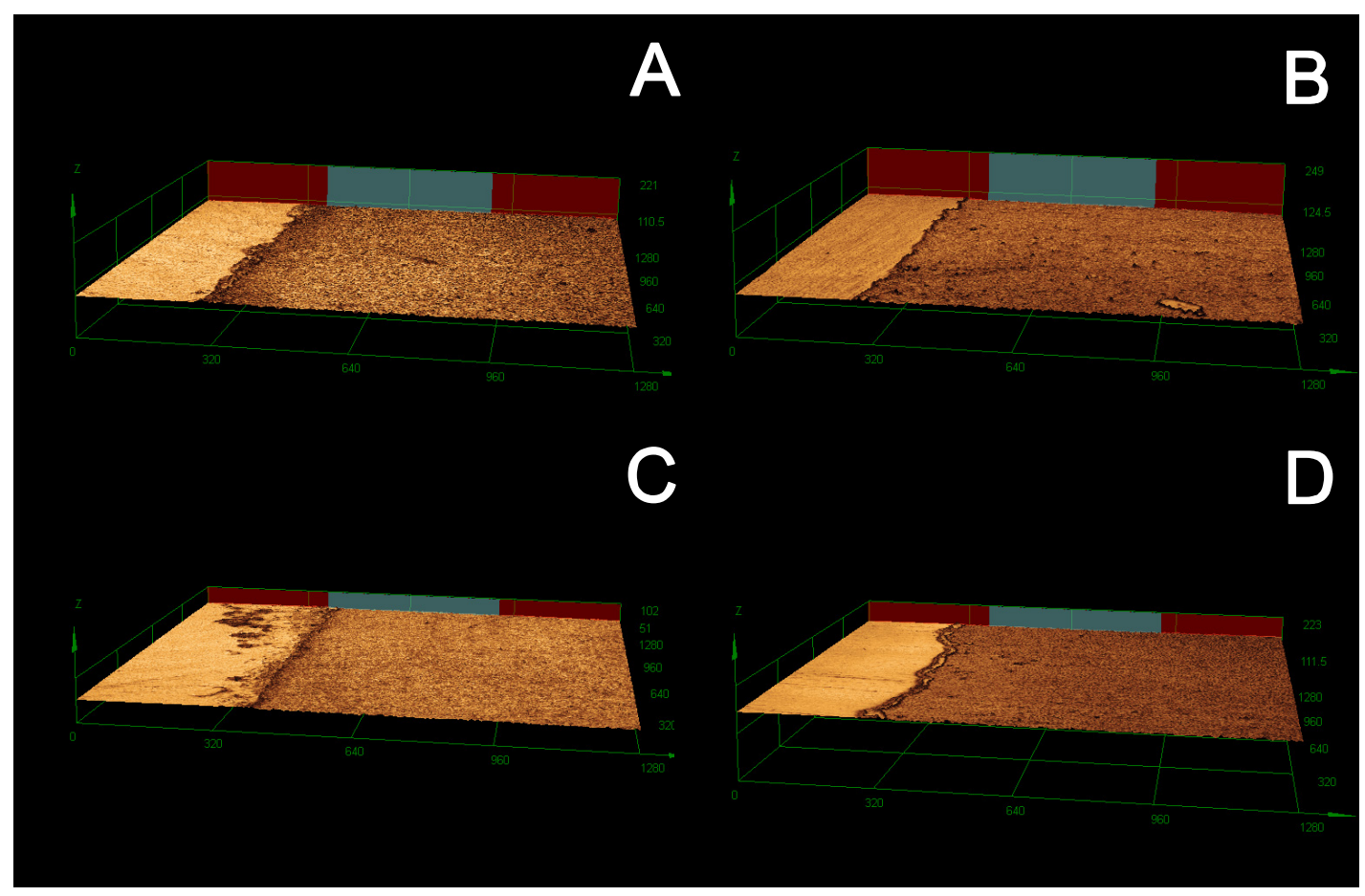

Figura 17. Dentina radicular, lado esquerdo representa a área referência do espécime (protegida) e o lado direito representa a área exposta ao desafio erosivo. A: Grupo CO. B: Grupo QRT. C: Grupo QTX. D: Grupo RTX. (Aumento de 216x)

Na Figura 18, observa-se na análise inicial da dentina que os túbulos dentinários encontravam-se parcialmente obliterados. Após o desafio erosivo, percebe-se que os túbulos aumentaram em diâmetro e quantidade, tornando-se abertos. O grupo CO (Figura 18a) aparenta ter maior quantidade de túbulos abertos comparados aos demais grupos. Observa-se também que os grupos de tratamento antineoplásico estão com o lúmen mais ampliado que as do grupo CO. 


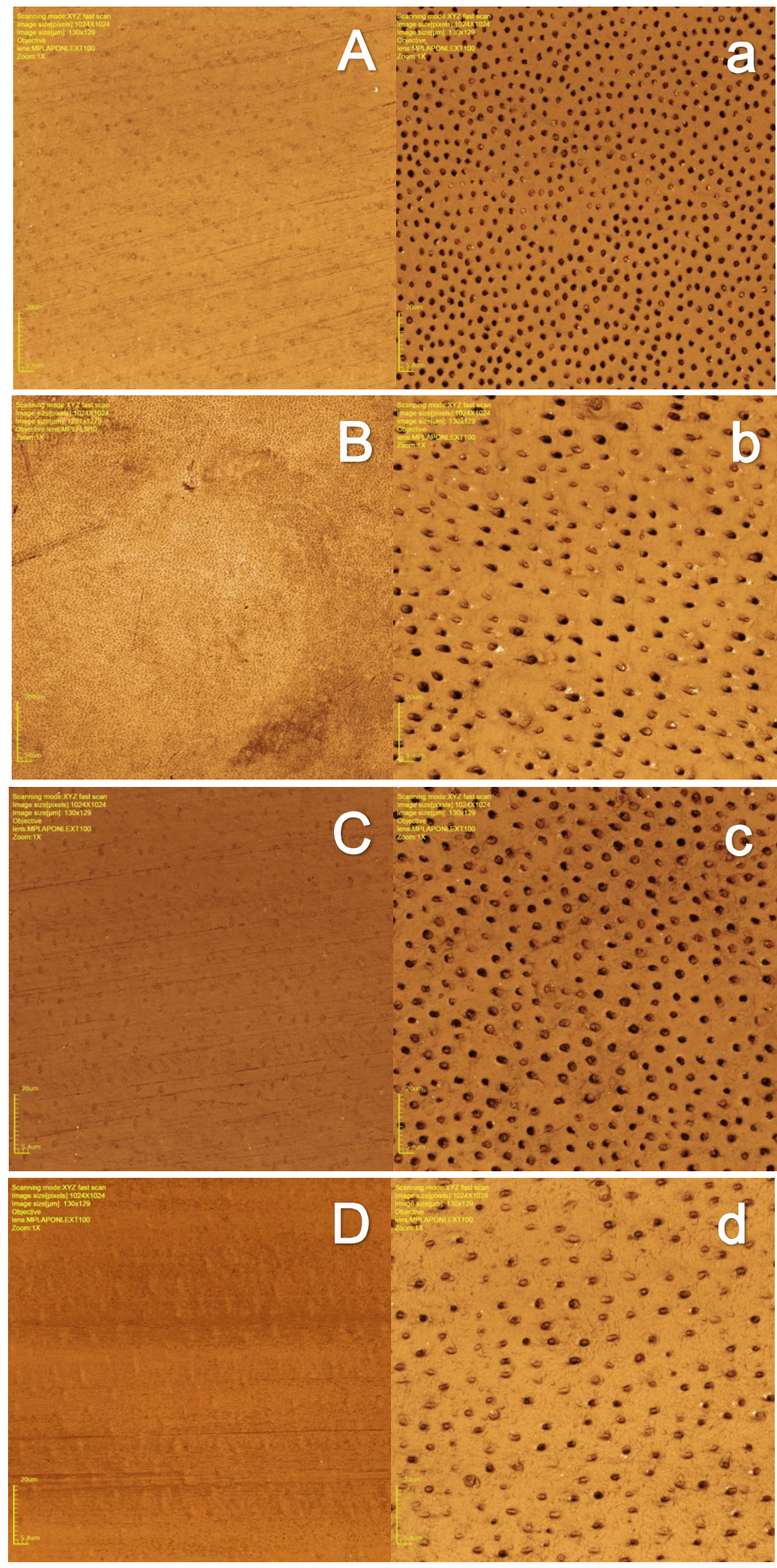

Figura 18. Dentina radicular, imagens do lado esquerdo representam as análises iniciais dos espécimes e as imagens do lado direito representam as análises após o desafio erosivo. A e a: Grupo CO. B e b: Grupo QRT. C e c: Grupo QTX. D e d: Grupo RTX. (Aumento de 2131x) 


\section{$\underline{2^{a} \text { fase - Indução de lesão de cárie in situ }}$}

Nas análises de perfil de desgaste, degrau formado, rugosidade e volume perdido não se observou diferença significante entre os grupos $(p>0,05)$ (Tabela 4). No volume perdido, todos os grupos foram estatisticamente semelhantes, tendo os grupos RTX e QRT os maiores valores (Figura 19).

Tabela 4. Média e desvio padrão dos grupos para perfil de desgaste ( $R v$ em $\mu \mathrm{m})$, degrau formado $(\mu \mathrm{m})$, rugosidade (Sa em $\mu \mathrm{m}$ ) e média, desvio padrão e mediana dos grupos para volume perdido $\left(\mu \mathrm{m}^{3}\right)$ para Indução de Cárie.

\begin{tabular}{c|cccc} 
& Perfil de desgaste & Degrau formado & Rugosidade & Volume perdido.10 \\
\hline CO & $0,71 \pm 0,32 \mathrm{a}$ & $5,75 \pm 5,85 \mathrm{~b}$ & $0,36 \pm 0,21 \mathrm{c}$ & $12,08 \pm 11,86(9,33) \mathrm{d}$ \\
\hline QRT & $0,94 \pm 0,36 \mathrm{a}$ & $6,34 \pm 2,50 \mathrm{~b}$ & $0,64 \pm 0,21 \mathrm{c}$ & $13,98 \pm 10,86(11,94) \mathrm{d}$ \\
\hline QTX & $0,69 \pm 0,26 \mathrm{a}$ & $3,80 \pm 2,28 \mathrm{~b}$ & $0,54 \pm 0,41 \mathrm{c}$ & $8,24 \pm 5,08(9,11) \mathrm{d}$ \\
\hline RTX & $0,86 \pm 0,37 \mathrm{a}$ & $7,23 \pm 3,62 \mathrm{~b}$ & $0,56 \pm 0,47 \mathrm{c}$ & $16,58 \pm 13,87(12,66) \mathrm{d}$ \\
\hline
\end{tabular}

*Letras iguais indicam semelhança estatística na mesma coluna para os diferentes grupos.

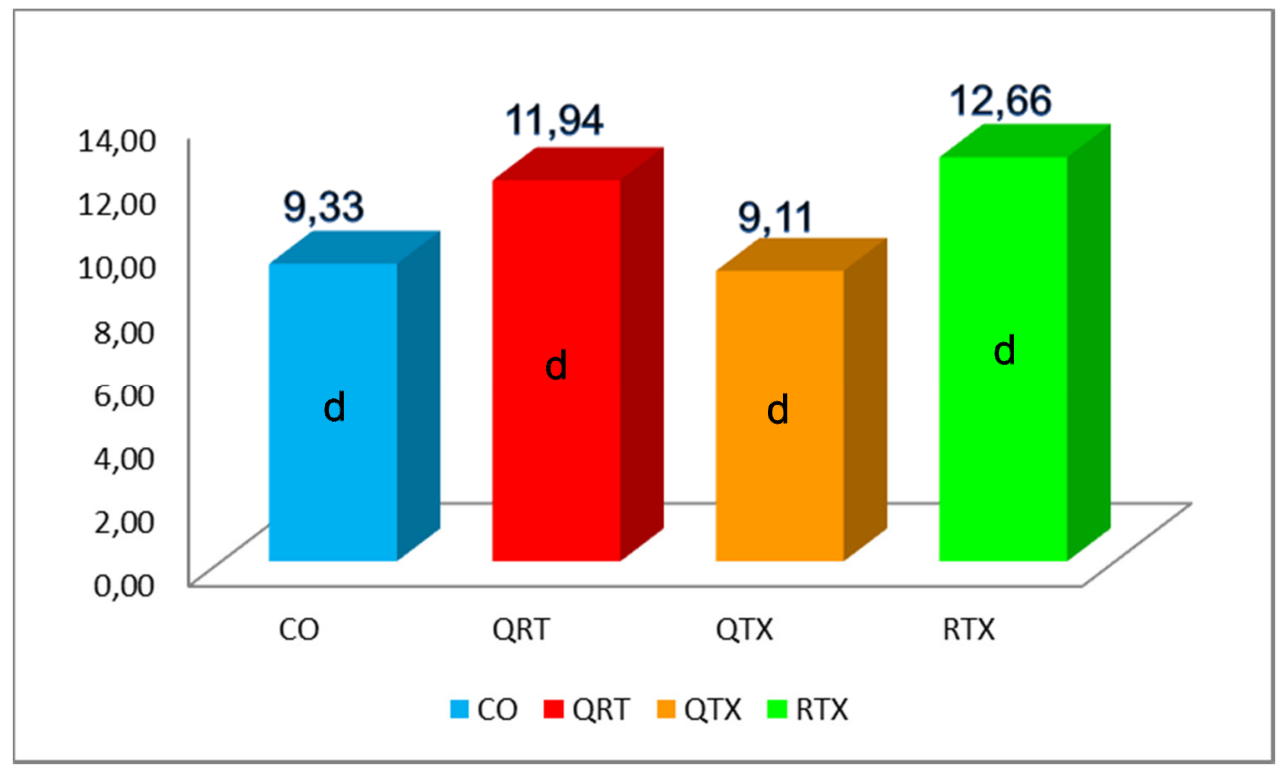

Figura 19. Gráfico representativo da mediana para volume perdido para a fase de Indução de Cárie.

De acordo com os dados obtidos, não foi encontrada diferença estatística significante entre os grupos para a análise de quantificação de tecido desmineralizado por tomografia de coerência óptica para indução de cárie $(p>0,05)$ (Tabela 5). Os grupos CO e QRT apresentaram os maiores valores, 
sendo o menor valor correspondente ao grupo QTX (Figura 20).

Tabela 5. Médias e desvio padrão dos grupos para a fase de indução de cárie para quantificação do tecido desmineralizado.

\begin{tabular}{cc}
\hline \multicolumn{2}{c}{$2^{\text {a }}$ Fase -Cárie } \\
\hline CO & $9,31 \pm 7,81(8,75) \mathrm{a}$ \\
\hline QRT & $9,32 \pm 7,57(8,60) \mathrm{a}$ \\
\hline QTX & $5,07 \pm 5,06(3,28) \mathrm{a}$ \\
\hline RTX & $6,54 \pm 4,86(5,59) \mathrm{a}$ \\
\hline
\end{tabular}

*Letras iguais indicam semelhança estatística para os diferentes grupos.

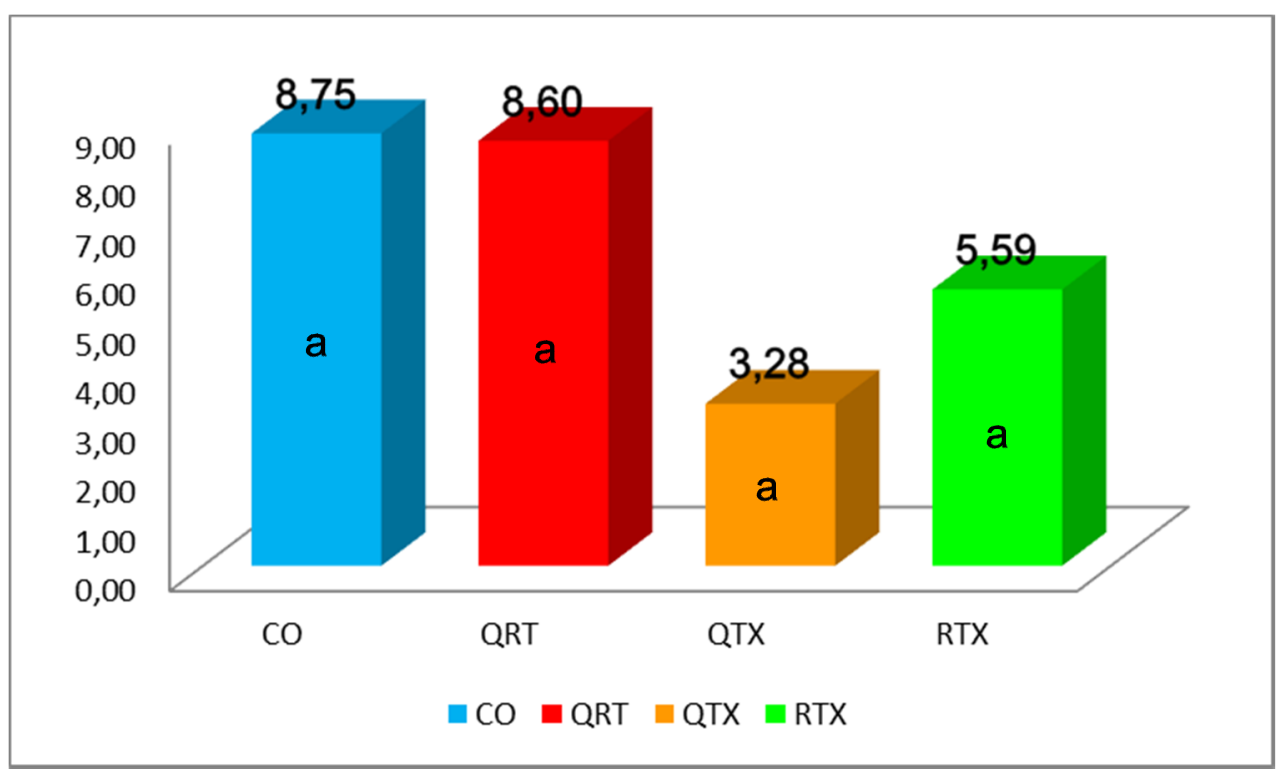

Figura 20. Gráfico representativo da mediana para quantificação do tecido desmineralizado para a fase de Indução de Cárie.

\section{Morfologia de superfície}

As imagens mais representativas obtidas por microscopia confocal a laser para cárie estão apresentadas nas Figuras 21 e 22. Após o desafio cariogênico (lado direito das imagens), nota-se a presença de um tecido amorfo e desorganizado. O grupo QRT (Figura 21B) aparenta ter a maior desmineralização e desorganização do tecido dentre os grupos, seguido pelo 
grupo RTX (Figura 21D). Os grupos CO (Figura 21A) e QTX (Figura 21C) apresentaram morfologicamente imagens muito semelhantes entre si.

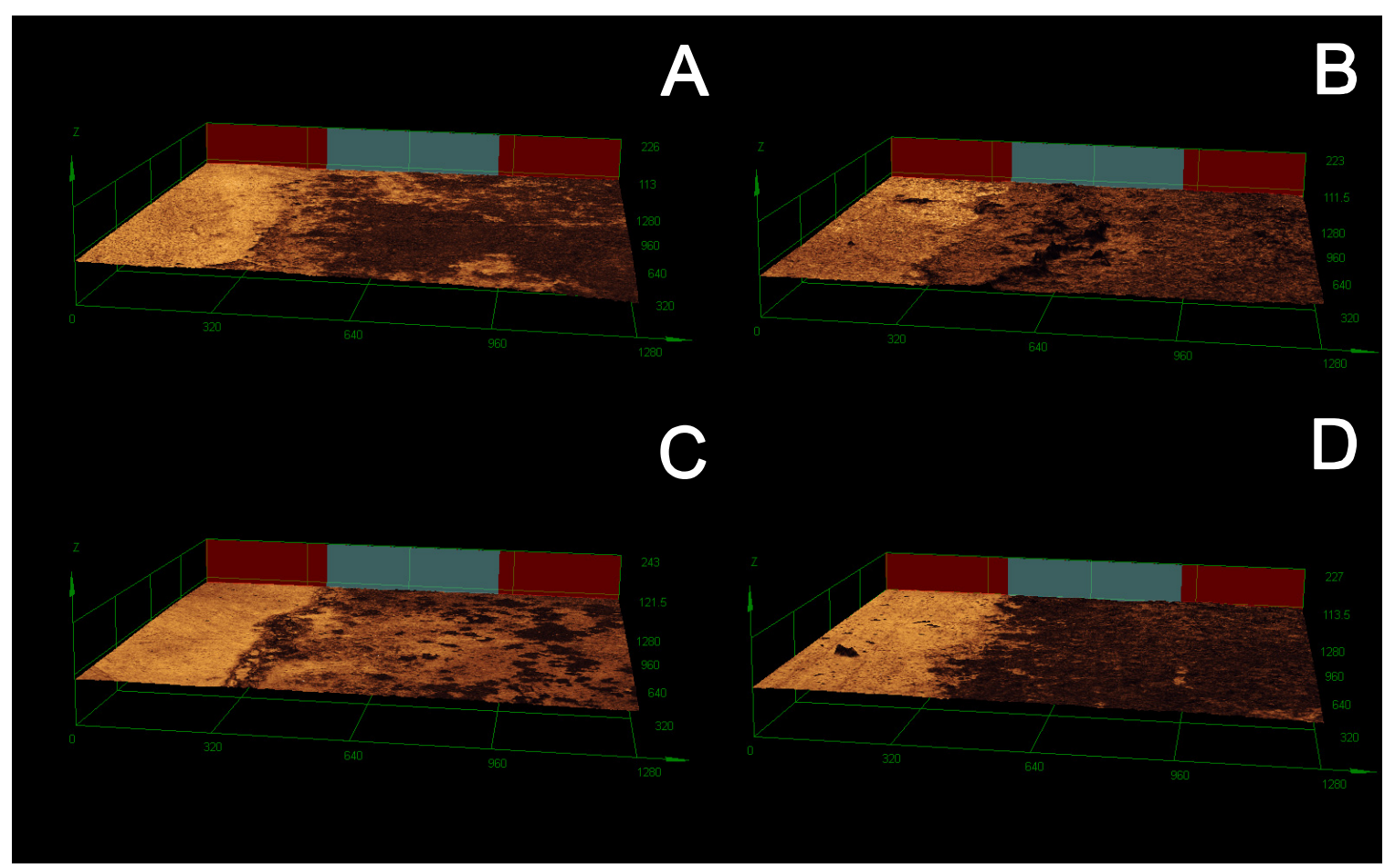

Figura 21. Dentina radicular, lado esquerdo representa a área referência do espécime (protegida) e o lado direito representa a área exposta ao desafio cariogênico. A: Grupo CO. B: Grupo QRT. C: Grupo QTX. D: Grupo RTX. (Aumento de 216x)

Quanto aos túbulos dentinários (Figura 22), estes se encontravam parcialmente abertos, bem organizados e com a porção peritubular e intertubular bem definidas na área referência. Após o desafio cariogênico, observou-se desorganização e degradação dos túbulos e de toda região intertubular e peritubular, perdendo sua forma e tornando difícil sua identificação. Percebe-se nitidamente que o grupo RTX (Figura 22d) apresentou uma dentina muito mais degradada do que os outros grupos, com material amorfo sobre a superfície.

Dessa forma, as análises quantitativas de número, área e perímetro dos túbulos dentinários tornaram-se inviabilizadas devido às tais alterações morfológicas superficiais ocorridas após a indução de cárie. 

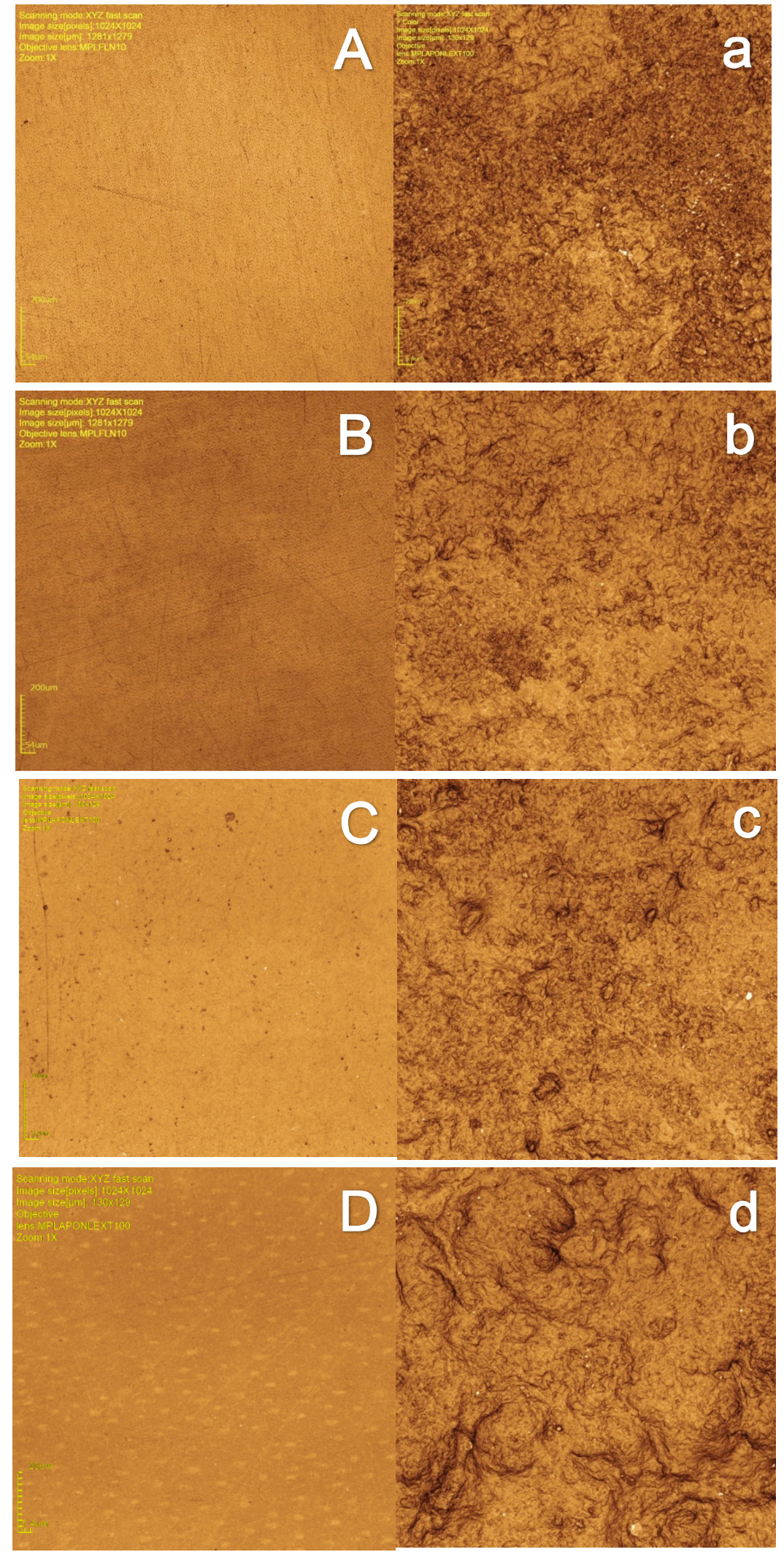

Figura 22. Dentina radicular, imagens do lado esquerdo representam as análises iniciais dos espécimes e as imagens do lado direito representam as análises após o desafio cariogênico. A e a: Grupo CO. B e b: Grupo QRT. C e c: Grupo QTX. D e d: Grupo RTX. (Aumento de 2131x) 


\section{$\underline{3^{a} \text { fase - Ensaio de abrasão in vitro }}$}

De acordo com os dados obtidos, não foi encontrada diferença estatística significante entre os grupos para as análises de perfil de desgaste, degrau formado e rugosidade ( $p>0,05)$, havendo diferença apenas para a análise de volume perdido, na qual, o grupo RTX apresentou o valor mais elevado comparado aos outros (Figura 23) e estatisticamente significante $(p<0,05)$, sendo que os outros grupos foram semelhantes entre si. ( $p>0,05)$ (Tabela 6).

Tabela 6. Média e desvio padrão dos grupos para perfil de desgaste ( $R v$ em $\mu \mathrm{m})$, degrau formado $(\mu \mathrm{m})$, rugosidade (Sa em $\mu \mathrm{m})$ e média, desvio padrão e mediana dos grupos para volume perdido $\left(\mu \mathrm{m}^{3}\right)$ para Ensaio de Abrasão.

\begin{tabular}{c|cccr} 
& Perfil de desgaste & Degrau formado & Rugosidade & Volume perdido.106 \\
\hline CO & $2,47 \pm 1,92 \mathrm{a}$ & $41,20 \pm 16,27 \mathrm{~b}$ & $1,51 \pm 1,29 \mathrm{c}$ & $34,17 \pm 16,46(28,33) \mathrm{de}$ \\
\hline QRT & $3,45 \pm 3,40 \mathrm{a}$ & $47,32 \pm 16,42 \mathrm{~b}$ & $1,59 \pm 1,49 \mathrm{c}$ & $37,81 \pm 11,20(33,89) \mathrm{de}$ \\
\hline QTX & $1,60 \pm 0,81 \mathrm{a}$ & $41,42 \pm 14,95 \mathrm{~b}$ & $0,87 \pm 0,77 \mathrm{c}$ & $29,75 \pm 12,33(29,57) \mathrm{d}$ \\
\hline RTX & $2,51 \pm 1,49 \mathrm{a}$ & $55,29 \pm 29,41 \mathrm{~b}$ & $1,41 \pm 1,24 \mathrm{c}$ & $45,54 \pm 23,60(43,33) \mathrm{e}$ \\
\hline
\end{tabular}

*Letras iguais indicam semelhança estatística na mesma coluna para os diferentes grupos.

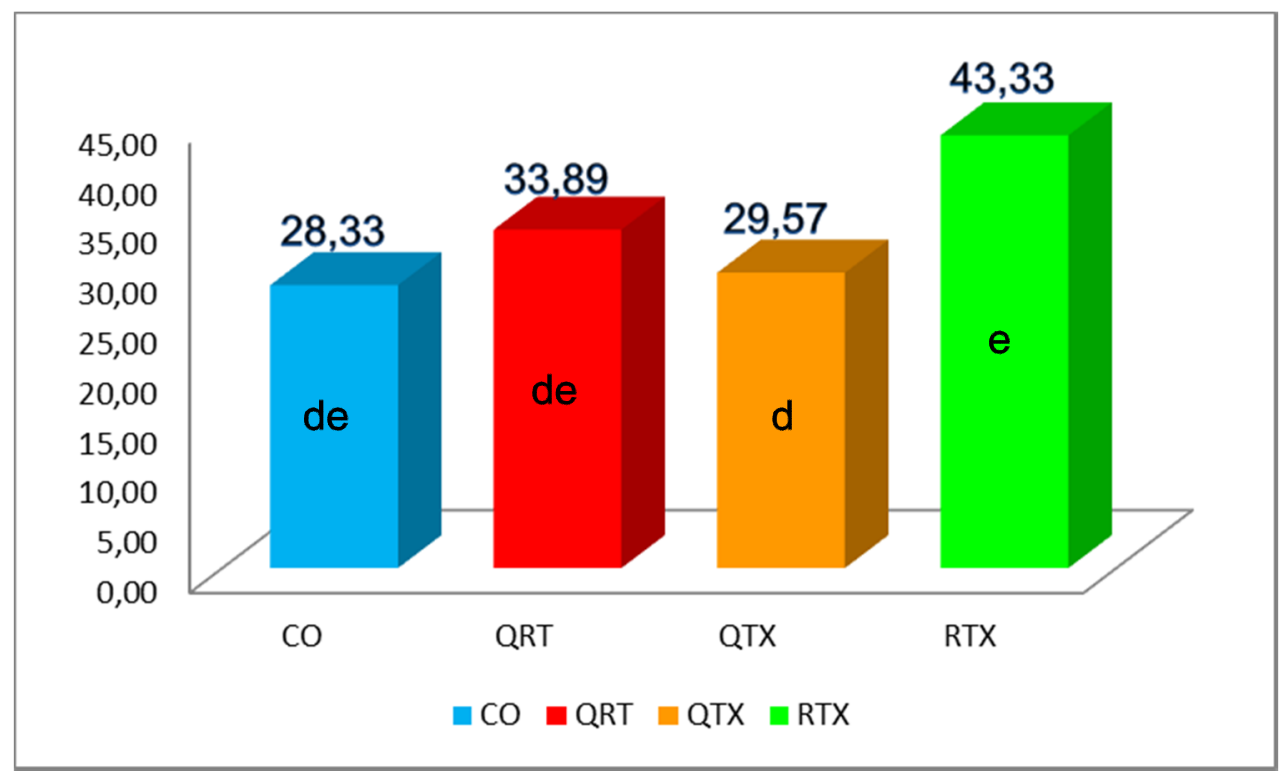

Figura 23. Gráfico representativo da mediana para volume perdido para a fase de Abrasão. 
Morfologia de superfície

Após o ensaio de escovação do fragmento (lado direito das imagens), o tecido apresentou-se desgastado e abrasonado. Os grupos QRT (Figura 24B) e RTX (Figura 24D) apresentaram um desgaste excessivo, formando canaletas no substrato de acordo com o formato das cerdas da escova. Todos os grupos apresentaram grande perda de estrutura dentinária.

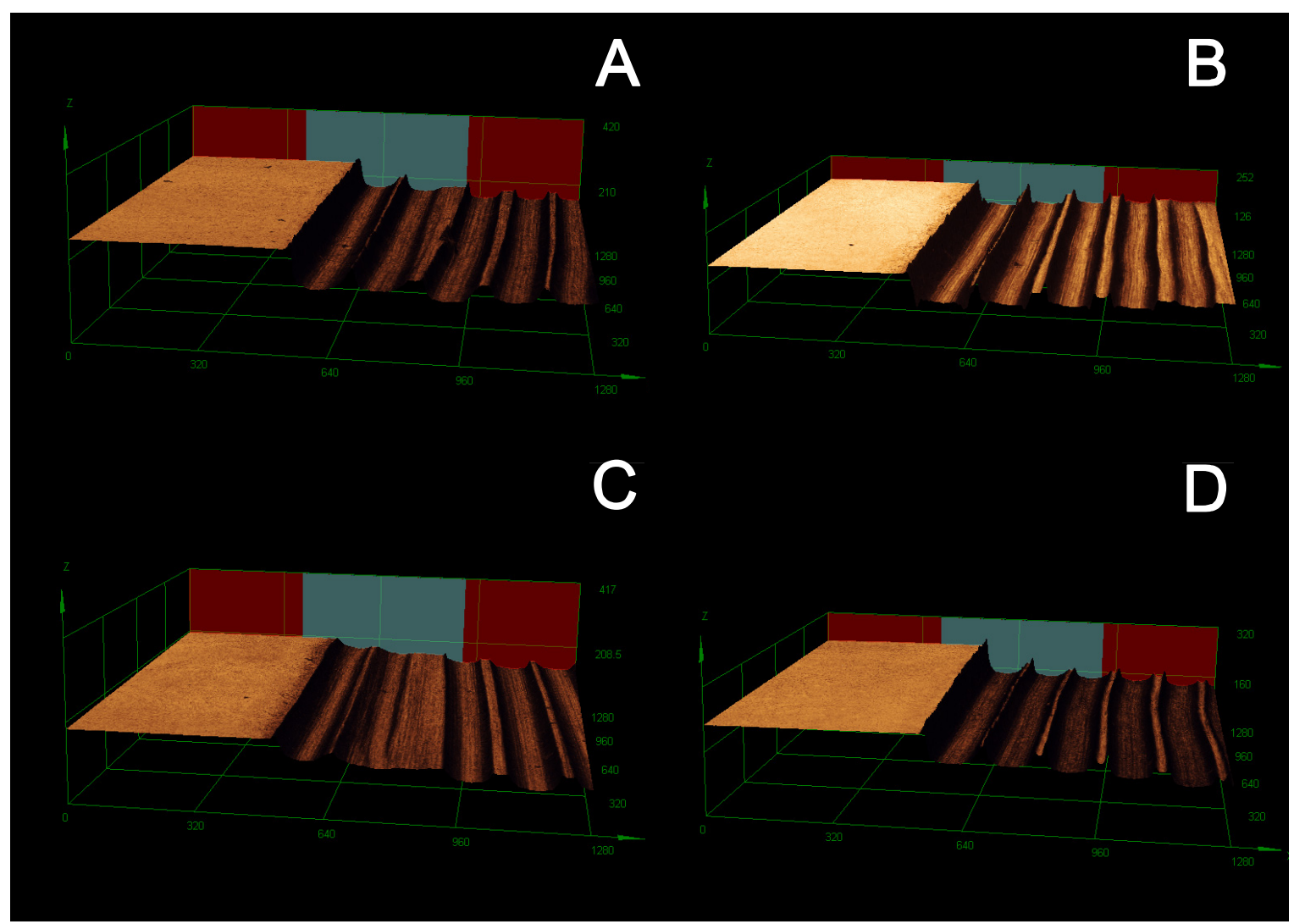

Figura 24. Dentina radicular, lado esquerdo representa a área referência do espécime (protegida) e o lado direito representa a área exposta ao desafio abrasivo. A: Grupo CO. B: Grupo QRT. C: Grupo QTX. D: Grupo RTX. (Aumento de 216x) 



\section{Discussão}





\section{DIscuSsão}

A assistência odontológica ao paciente com câncer consiste não apenas no atendimento para reduzir os problemas básicos de saúde bucal, como a cárie, erosão e abrasão, mas também relacionado aos efeitos colaterais do tratamento antineoplásico. Graças ao diagnóstico precoce da doença, bem como, aos avanços nos tratamentos (Tsai et al., 2016; Eskiizmir et al., 2017), cada vez mais pacientes apresentam uma maior sobrevida e conseguem manter sua dentição natural até idades mais avançadas (Nekhlyudov et al., 2017; Wang et al., 2017). Dessa forma, os dentes destes pacientes ficam expostos aos diferentes fatores etiológicos por um período de tempo maior do que era esperado nas décadas passadas.

Entretanto, apesar da quimioterapia e radioterapia interferirem nos hábitos e na qualidade de vida do paciente (Weis, 2017), ainda não há um consenso sobre como os tratamentos antineoplásicos alteram os tecidos dentais duros e como essas mudanças podem contribuir para a maior susceptibilidade à erosão, cárie ou abrasão. Sabe-se que a radioterapia atua por meio da quebra de moléculas de água, formando radicais livres reativos como oxigênio e hidrogênio, que podem alterar os componentes orgânicos das estruturas dentais (Pioch, 1992; Fang, 2002). Por sua vez a quimioterapia pode comprometer as estruturas do dente devido à alteração de fluxo e liberação da medicação na cavidade bucal (Oton-Leite, 2015; Morais, 2017).

Somado a isso, fatores psicológicos, como estresse e depressão, podem ser considerados fatores críticos na etiologia e progressão das lesões dentais, favorecendo a inflamação e recessão gengival, e consequentemente a exposição da raiz (Grippo, 2004; Barata, 2010; Rathva, 2011). Assim, o substrato avaliado neste estudo foi a dentina radicular. Esse tecido possui em sua composição, em volume, aproximadamente de $45 \%$ de conteúdo mineral, 33\% de conteúdo orgânico (90\% representado por colágeno tipo I) e $22 \%$ de água (Tjäderhane et al, 2012). Por apresentar elevado teor de água e colágeno, a dentina é considerada um tecido vulnerável aos efeitos da radiação (Gonçalves 
et al., 2014) e mais susceptível quando exposta ao meio bucal (Barata, 2010).

Trabalhos in vitro, visando avaliar o efeito da radioterapia sobre os diferentes substratos, sugerem que a radiação modifica as propriedades dentais, como alteração da dureza tanto para mais (Rodrigues, 2017) quanto para menos (Gonçalves et al., 2014; Lieshout \& Bots, 2014; Qing et al., 2016), promove a diminuição do módulo de elasticidade e da força de microtração (Rodrigues, 2017), tanto aumento da atividade das MMPs (Bonilla, 2016) quanto inalteração da atividade de MMPs (Wagner-Gomes, 2017), desorganização do esmalte e da dentina resultando em uma superfície dental amorfa (Goncalves et al., 2014; Arid, 2015; de Siqueira Mellara, 2016) e degradação da fibras colágenas (McGuire et. al., 2014; Rodrigues, 2017) acompanhada pela obliteração dos túbulos dentinários (Kielbassa, 2000, Gonçalves et al., 2014). O presente estudo observou que qualitativamente a radioterapia favoreceu o desenvolvimento do processo de cárie, erosão e desgaste, e quantitativamente favoreceu a perda de estrutura dentinária para o desafio abrasivo. Esses resultados estão de acordo com a literatura (Goncalves et al., 2014; Arid, 2015; de Siqueira Mellara, 2016; Rodrigues, 2017) em que se observam resultados semelhantes na degradação das fibras colágenas e deformação permanente da estrutura provavelmente devido a alteração do módulo de elasticidade dentinária.

O tratamento quimioterápico concomitante ao radioterápico (QRT) afetou de forma quantitativa o substrato no processo erosivo. Observou-se uma maior perda de tecido, em volume, sugerindo um sinergismo dos tratamentos, possivelmente devido a alguma alteração ocasionada pela liberação salivar de componentes dos agentes quimioterápicos. Provavelmente tal alteração do processo de remineralização ocorreu em função do fluxo e composição salivar do paciente ter sido alterada (Oton-Leite, 2015; Bomfim, 2017; Morais, 2017).

A alteração de fluxo salivar em pacientes oncológicos é bem estabelecida na literatura (Jensen, 2008; Toscano, 2009; Oton-Leite, 2015). Quanto à excreção de quimioterápicos por via salivar (Araújo, 2015; Paiva, 2016; Morais, 2017), alguns autores (Benites, 2015, Bomfim, 2017) já demonstraram a presença do 5- fluorouracil na saliva de pacientes tratados pelo quimioterápico. Este quimioterápico é frequentemente utilizado em conjunto com a cisplatina, sendo indicado para casos de câncer de laringe e nasofaringe (Janoray, 2015; 
Ma, 2016). Quanto à monoterapia com cisplatina, a presença de platina na saliva de pacientes parece ocorrer durante, ou imediatamente após a infusão do quimioterápico (Holding, 1999).

Tais alterações salivares fazem com que, em muitos casos, se torne difícil a higienização bucal devido à diversos fatores como dor relacionada ao aparecimento das mucosites, perda do paladar, trismo, náuseas e vômitos (Naidu et al.,2004; Amaral, 2009; Simões et al, 2009; Araújo, 2015; Jesus, 2016; Paiva, 2016; Morais, 2017), desta forma, favorecendo o acúmulo da placa bacteriana. Além disso, essas condições fazem com que o paciente tenha preferência pela alimentação mais pastosa e doce, e consequentemente mais cariogênica (Lieshout e Bots, 2014). A soma de todos estes fatores levam ao aumento da susceptibilidade dos tecidos à lesão de cárie.

A cárie dentária é processo altamente destrutivo dos tecidos mineralizados, devido à atividade bacteriana na cavidade bucal e pode ser descrita como um processo de desmineralização-remineralização dos tecidos mediada por microrganismos (Larsen e Brun, 1995; Pitts, 2017). Entretanto, quando se trata de um paciente sob tratamento com radiação, utiliza-se o termo "cárie relacionada à radiação" ou apenas "cárie de radiação", tendo essas lesões cariosas características similares às lesões de cárie comum, contudo mostrandose mais agressivas (Kielbassa et al., 2006; Silva, 2009). Entre as características desse tipo de lesão está a progressão rápida e geralmente indolor (Jansma et al, 1993; Kielbassa et al., 2006; Walker et al., 2001). Na maioria das vezes, essas lesões cariosas apresentam coloração marrom e estão localizadas na região da junção amelodentinária, de forma a circundar a área cervical dos dentes (Jansma et al, 1993; Silva et al., 2009; Walker, 2011).

A evolução dessa alteração está relacionada à diminuição do fluxo salivar, reduzindo assim a efetividade da saliva em promover sua ação tampão e de limpeza, tornando o pH bucal ácido. Conscientes de tais alterações, muitos autores (Santos-Silva, 2015; Gomes-Silva, 2017; Madrid, 2017) acreditam que essas mudanças salivares induzidas pelo tratamento antineoplásico sejam as principais causas da severidade da cárie relacionada à radiação. Neste estudo, o padrão carioso das lesões nos grupos de tratamento antineoplásico não se mostraram estruturalmente diferentes das lesões cariosas do grupo controle 
(CO), contudo nota-se, morfologicamente, uma maior desorganização e acúmulo de material amorfo nas lesões cariosas do grupo QRT, sugerindo uma maior susceptibilidade à cárie nesse grupo.

No presente estudo, além do CLSM, foi realizada a análise das amostras em OCT, onde foi possível realizar imagens 2D em profundidade quantificando a desmineralização na superfície dentinária por meio de cortes tomográficos do espécime, permitindo avalias anormalidades superficiais e fornecendo imagens estruturais em tempo real. (Mercut, 2017). Na análise do grau de desmineralização do tecido após os processos erosivo e de cárie por meio de OCT, observou-se que não houve diferença de comportamento entre os tratamentos. A ausência de diferença provavelmente se deu pelo tempo de exposição aos desafios, talvez o aumento do tempo poderia refletir numa diferença de comportamento, ou mesmo as condições controladas desse estudo podem ter afetado o desenvolvimento dos processos.

Outros fatores analisados que não alteraram conforme o tipo de tratamento antineoplásico empregado foram as características da dentina. Observou-se um aumento no número, área e perímetro dos túbulos dentinários expostos após os desafios erosivos, assim como já evidenciado por outros autores (Meurman, Drysdale, \& Frank, 1991; Aksel, 2016). Como era esperado, (Jansma et al, 1993; Kielbassa et al., 2006; Hedenbjörk-Lager, 2016; GomesSilva, 2017), durante o desafio cariogênico, a ação da DES-RE promoveu uma desorganização estrutural que refletiu na obliteração dos túbulos e exposição de um material amorfo sobre a superfície. Esse fato provavelmente ocorreu devido à ação do processo de metabolização dos microrganismos que promovem também a degradação da porção orgânica da dentina (Larsen e Brun, 1995; Gonçalves et al., 2014; Hedenbjörk-Lager, 2016; Pitts, 2017).

Além do processo químico da erosão e químico-microbiológico de cárie, com o passar dos anos, é natural e inevitável que os tecidos duros bucais sofram o processo físico da abrasão. A abrasão pode ocorrer como resultado da escovação traumática prolongada ou uso incorreto de fio dental e palitos de dentes, sendo que quantidade de desgaste causada pela escovação depende principalmente do hábito, da qualidade da escova e do dentifrício utilizado (Wang, 2004). Outras causas do desgaste dental são os hábitos bucais 
deletérios como morder objetos, roer unhas e mascar tabaco, tendo este último, estreita relação com o desenvolvimento do câncer bucal (Leite, 2005; De Freitas, 2016), porém poucos estudos correlacionam os tratamentos antineoplásicos ao maior desgaste de estrutura dentária.

Estudos anteriores demonstraram in vitro que o substrato irradiado apresenta alteração de algumas de suas propriedades (Gonçalves et al., 2014; Lieshout \& Bots, 2014; Qing et al., 2016; Santin, 2015; Rodrigues, 2017), dentre elas, a menor resistência ao desgaste (Qing, 2015; Qing, 2016). Esta alteração pode ser observada no presente estudo, em que o grupo RTX foi mais susceptível à perda, em volume, de estrutura dentinária tanto qualitativamente quanto quantitativamente.

As divergências nos resultados encontrados na literatura e no presente trabalho podem estar vinculadas à metodologia da pesquisa. Trabalhos prévios (Qing, 2015; Qing 2016) quando da análise do desgaste dental, utilizaram espécimes doados por pacientes saudáveis (ou antes que tivessem recebido algum tratamento antineoplásico), sendo a radioterapia foi realizada apenas após a extração dental. Neste estudo, o substrato analisado foi a dentina radicular de dentes de pacientes que receberam o tratamento antes da sua extração, sendo esta realizada devido a problemas periodontais ou cárie profunda na coroa, portanto, a radiação foi realizada com os dentes ainda em boca, tendo assim, um substrato em ambiente real, com as condições que ocorrem durante o tratamento.

Após os tratamentos antineoplásicos, ocorreram alterações estruturais e morfológicas da dentina radicular, porém a literatura ainda é muito limitada sobre esses efeitos. Verificou-se que estes tecidos podem responder de forma diferenciada ao tecido normal quando expostos aos diferentes processos bucais como erosão, cárie e abrasão.

Assim, mais estudos são necessários para aumentar a compreensão dos pesquisadores e clínicos sobre os efeitos dos tratamentos antineoplásicos sob a integridade da cavidade bucal e buscar meios de minimizar tais efeitos colaterais. A pesquisa nesta área deve ser estimulada a fim de que surjam eficientes alternativas preventivas e reabilitadoras para devolver a qualidade de vida não apenas aos pacientes submetidos ao tratamento de câncer de cabeça e 
pescoço, mas também a todos os pacientes portadores de neoplasias com efeitos colaterais na cavidade bucal. 



\section{CONCLUSÃo}

Diante dos resultados encontrados no presente estudo, pode-se concluir que os tratamentos antineoplásicos alteraram a dentina radicular e influenciaram nos processos erosivo, carioso e abrasivo. A quimioterapia teve um efeito mais ameno no substrato quando comparada aos outros tratamentos. Contudo, quando a quimioterapia é realizada concomitante à radioterapia, ocorreu grande perda de estrutura para o processo de erosão, sendo que, morfologicamente, percebe-se um aumento no número e perímetro dos túbulos dentinários para todos os grupos de tratamentos. A radioterapia causou nítida perda tecidual para abrasão e alterou morfologicamente com maior intensidade a dentina radicular tanto para o ensaio abrasivo quanto para o desafio cariogênico. 

Referências 



\section{REFERÊNCIAS}

1. Dobrossy L. Epidemiology of head and neck cancer: magnitude of the problem. Cancer Metastasis Rev. 2005; Jan;24(1):9-17.

2. Rettig EM, D'Souza G. Epidemiology of head and neck cancer. Surg Oncol Clin N Am. 2015; Jul;24(3):379-96.

3. Lemaire $F$, et al. Differential expression profiling of head and neck squamous cell carcinoma (HNSCC). Br J Cancer. 2003; Nov 17;89(10):1940-9.

4. Lothaire $P$, et al. Molecular markers of head and neck squamous cell carcinoma: promising signs in need of prospective evaluation. Head Neck. 2006; Mar;28(3):256-69.

5. INCA. Incidência de Câncer no Brasil. Estimativa 2016 http://www.inca.gov.br/estimativa/2016/sintese-de-resultados-comentarios.asp: INCA; 2016.

6. Wu, BC. et al. Bacterial alterations in salivary microbiota and their association in oral cancer. Scientific Reports. 2017; 7(1): 16540.

7. Overman VP. The Oral Cancer Foundation. Int J Dent Hyg. 2009; Aug;7(3):229-30.

8. Kim ES, Hong WK, Khuri FR. Chemoprevention of aerodigestive tract cancers. Annu Rev Med. 2002; 53:223-43.

9. Hashibe M, et al. Interaction between tobacco and alcohol use and the risk of head and neck cancer: pooled analysis in the International Head and Neck Cancer Epidemiology Consortium. Cancer Epidemiol Biomarkers Prev. 2009; Feb;18(2):541-50.

10. Jemal A, et al. Global cancer statistics. CA Cancer J Clin. 2011 MarApr;61(2):69-90.

11. Zhou J, et al. Smokeless tobacco and risk of head and neck cancer: evidence from a case-control study in New England. Int J Cancer. 2013; Apr 15;132(8):1911-7.

12. Gaudet MM, et al. Anthropometry and head and neck cancer:a pooled analysis of cohort data. Int J Epidemiol. 2015; Apr;44(2):673-81. 
13. Marur S, Forastiere AA. Head and Neck Squamous Cell Carcinoma:Update on Epidemiology, Diagnosis, and Treatment. Mayo Clin Proc. 2016; Mar;91(3):386-96.

14. Hashibe $\mathrm{M}$, et al. Alcohol drinking in never users of tobacco, cigarette smoking in never drinkers, and the risk of head and neck cancer: pooled analysis in the International Head and Neck Cancer Epidemiology Consortium. J Natl Cancer Inst. 2007; May 16;99(10):777-89.

15. Menvielle G, et al. Smoking, alcohol drinking and cancer risk for various sites of the larynx and hypopharynx. A case-control study in France. Eur $\mathrm{J}$ Cancer Prev. 2004; Jun;13(3):165-72.

16. Blot WJ, et al. Smoking and drinking in relation to oral and pharyngeal cancer. Cancer Res. 1988; Jun 1;48(11):3282-7.

17. Smith EM, et al. Age, sexual behavior and human papillomavirus infection in oral cavity and oropharyngeal cancers. Int J Cancer. 2004; Feb 20;108(5):76672.

18. Pintos $\mathrm{J}$, et al. Human papillomavirus infection and oral cancer: a casecontrol study in Montreal, Canada. Oral Oncol. 2008; Mar;44(3):242-50.

19. Chowdhury, $\mathrm{AH}$ et al. Prevalence and types of high-risk human papillomaviruses in head and neck cancers from Bangladesh. BMC cancer, 2017; 17(1): 792.

20. Tota JE, et al. Epidemiology and burden of HPV infection and related diseases: implications for prevention strategies. Prev Med. 2011 Oct;53 Suppl $1:$ S12-21.

21. Herrero R, et al. Human papillomavirus and oral cancer: the International Agency for Research on Cancer multicenter study. J Natl Cancer Inst. 2003 Dec 3;95(23):1772-83.

22. Gillison ML, Alemany L, Snijders PJ, Chaturvedi A, Steinberg BM, Schwartz S, et al. Human papillomavirus and diseases of the upper airway: head and neck cancer and respiratory papillomatosis. Vaccine. 2012 Nov 20;30 Suppl 5:F34-54.

23. Chan, $\mathrm{KK}$, et al. Interventions for the treatment of oral and oropharyngeal cancers: targeted therapy and immunotherapy. status and date: New, published in. 2013; (2). 
24. Qing P, Huang S, Gao S, Qian L, Yu H. Effect of gamma irradiation on the wear behaviour of human tooth enamel. Sci Rep. 2015;5:11568.

25. Spiotto, MT et al. Differences in Survival With Surgery and Postoperative Radiotherapy Compared With Definitive Chemoradiotherapy for Oral Cavity Cancer: A National Cancer Database Analysis. JAMA Otolaryngology-Head \& Neck Surgery, 2017.

24. Adelstein DJ. Systemic chemotherapy for squamous cell head and neck cancer. Expert Opin Pharmacother. 2003 Dec;4(12):2151-63.

26. Soares CJ, et al. Effects of chlorhexidine and fluoride on irradiated enamel and dentin. J Dent Res. 2011 May;90(5):659-64.

27. Nowara E, Suwinski R. Time factor in radiotherapy and chemotherapy for limited disease small-cell lung cancer. Cancer Invest. 2007 Apr-May;25(3):16371.

28. Seiwert TY, et al. A phase I trial of docetaxel based induction and concomitant chemotherapy in patients with locally advanced head and neck cancer. Cancer Invest. 2007 Sep;25(6):435-44.

29. Kielbassa AM, et al. Radiation-related damage to dentition. Lancet Oncol. 2006 Apr;7(4):326-35.

30. Silva AR, et al. Patterns of demineralization and dentin reactions in radiation-related caries. Caries Res. 2009;43(1):43-9.

31. Beech $\mathrm{N}$, et al. Dental management of patients irradiated for head and neck cancer. Aust Dent J. 2014 Mar;59(1):20-8.

32. Springer IN, et al. Radiation caries--radiogenic destruction of dental collagen. Oral Oncol. 2005 Aug;41(7):723-8.

33. Gonçalves LMN, et al. Radiation therapy alters microhardness and microstructure of enamel and dentin of permanent human teeth. J Dent. 2014 Aug;42(8):986-92.

34. Arid, Juliana. Efeito da radioterapia na adesão e interface ao substrato de dentes permanentes [dissertação]. Ribeirão Preto: Universidade de São Paulo, Faculdade de Odontologia de Ribeirão Preto; 2015. 
35. de Siqueira Mellara, T. Adesão de diferentes sistemas adesivos ao esmalte e à dentina de dentes decíduos submetidos à radioterapia [tese]. Ribeirão Preto: Universidade de São Paulo, Faculdade de Odontologia de Ribeirão Preto; 2016.

36. Jansma $\mathrm{J}$, et al. The effect of X-ray irradiation on the demineralization of bovine dental enamel. A constant composition study. Caries Res. 1988;22(4):199-203.

37. Kielbassa AM, et al. Irradiation effects on microhardness of fluoridated and non-fluoridated bovine dentin. Eur J Oral Sci. 1997 Oct;105(5 Pt 1):444-7.

38. Walker MP et al. Impact of Radiotherapy Dose on Dentition Breakdown in Head and Neck Cancer Patients. Pract Radiat Oncol. 2011;1(3):142-8.

39. Markitziu A, et al. In vitro irradiation effects on hardness and solubility of human enamel and dentin pretreated with fluoride. Clin Prev Dent. 1986 JulAug;8(4):4-7.

40. Kielbassa AM. In situ induced demineralization in irradiated and nonirradiated human dentin. Eur J Oral Sci. 2000 Jun;108(3):214-21.

41. Pioch T, Golfels D, Staehle HJ. An experimental study of the stability of irradiated teeth in the region of the dentinoenamel junction. Endod Dent Traumatol. 1992 Dec;8(6):241-4.

42. Troconis CCM. Análise estrutural do esmalte dental de pacientes com câncer de cabeça e pescoço submetidos à radioterapia [dissertação]. Piracicaba: Universidade Estadual de Campinas; 2016.

43. Bonilla C.C. Radioterapia ativa e inibidores de proteases inativam MMPs, na junção amelodentinária de dentes permanentes: Universidade de São Paulo; 2016.

44. Trotti A, et al. Mucositis incidence, severity and associated outcomes in patients with head and neck cancer receiving radiotherapy with or without chemotherapy: a systematic literature review. Radiother Oncol. 2003 Mar;66(3):253-62.

45. Murphy BA, et al. Quality of life research in head and neck cancer: a review of the current state of the science. Crit Rev Oncol Hematol. 2007 Jun;62(3):251-67.

46. Murphy BA, Gilbert J, Ridner SH. Systemic and global toxicities of head 
and neck treatment. Expert Rev Anticancer Ther. 2007 Jul;7(7):1043-53.

47. Deng J, et al. Dental demineralization and caries in patients with head and neck cancer. Oral Oncol. 2015 Sep;51(9):824-31.

48. Jones DL, Rankin KV. Management of the oral sequelae of cancer therapy. Tex Dent J. 2012 May;129(5):461-8.

49. Buglione M, Cavagnini R, Di Rosario F, Maddalo M, Vassalli L, Grisanti S, et al. Oral toxicity management in head and neck cancer patients treated with chemotherapy and radiation: Xerostomia and trismus (Part 2). Literature review and consensus statement. Crit Rev Oncol Hematol. 2016 Jun;102:47-54.

50. Almeida VLD. Câncer e agentes antineoplásicos ciclo-celular específicos e ciclo-celular não específicos que interagem com o DNA: uma introdução. Quim. Nova. 2005; 28(1), 118-129.

51. Krasuska-Slawinska $\mathrm{E}$, et al. Factors influencing caries incidence in permanent teeth in children/adolescents under and after anti-neoplastic treatment. Contemp Oncol (Pozn). 2016;20(1):45-51.

52. Chabner BA, Calabresi P. As Bases Farmacológicas da Terapêutica; Goodman, L. S.; Gilman, A., Ed. Mc Graw Hill: Rio de Janeiro, 1995, p. 903-949.

53. Altundag $\mathrm{O}$, et al. Cisplatin as a radiosensitizer in the treatment of locally advanced head and neck cancer. Oral Oncol. 2005; 41:435.

54. Bernier J, Vermorken JB, Koch WM. Adjuvant therapy in patients with resected poor-risk head and neck cancer. J Clin Oncol. 2006; 24:2629-2635.

55. Katz D, Ito E, Liu FF. On the path to seeking novel radiosensitizers. Int J Radiat Oncol Biol Phys. 2009 Mar 15;73(4):988-96.

56. Dasari S, Tchounwou P. Cisplatin in cancer therapy: molecular mechanisms of action. European journal of pharmacology. 2014; 740, 364-378v. 740, p. 364-378, 2014.

57. Almeida SMVD, et al. Compostos coordenados híbridos de platina no tratamento do câncer. Revista de Ciências Farmacêuticas Básica e Aplicada. 2015; 35(3):345.

58. Wang $\mathrm{C}$, et al. Molecular mechanisms of chemoresistance in oral cancer. Chin J Dent Res. 2016; 19(1):25-33. 
59. Viele CS. Overview of chemotherapy-induced diarrhea. In: Seminars in Oncology Nursing. WB Saunders. Nov 2003; 19:2-5.

60. Ewens AD, Mihich, E; Ehrke, MJ. Fluorouracil plus leucovorin induces submandibular salivary gland enlargement in rats. Toxicologic pathology. 2005; 33(4), 507-515.

61. Naidu MUR, et al. Chemotherapy-induced and/or radiation therapyinduced oral mucositis-complicating the treatment of cancer. Neoplasia. 2004; 6(5), 423-431.

62. Amaral SM, Miranda AMMA, Pires FR. Reações medicamentosas na cavidade oral: aspectos relevantes na estomatologia. Rev Bras Odontol. 2009; 66(1):41-53.

63. Simoes A, et al. Laser phototherapy as topical prophylaxis against head and neck cancer radiotherapy-induced oral mucositis: Comparison between low and high/low power lasers. Lasers in surgery and medicine, 2009; 41(4):264-270.

64. Araujo TLC, et al. Manifestações bucais em pacientes submetidos a tratamento quimioterápico. Rev Cubana Estomatol. 2015; 52(4):16-21.

65. Jesus LGD, et al. Repercussões orais de drogas antineoplásicas: uma revisão de literatura. RFO UPF. 2016; 21(1):130-135.

66. Paiva $\mathrm{Cl}$, et al. Efeitos da quimioterapia na cavidade bucal. Disciplinarum Scientia| Saúde. 2016; 5(1):109-119.

67. Morais ÂMD, et al. Estudo das manifestações bucais em pacientes tratados com quimioterapia. Journal of Orofacial Investigation. 2017; 4(1):49-59.

68. Nekhlyudov L, et al. Head and Neck Cancer Survivorship Care Guideline: American Society of Clinical Oncology Clinical Practice Guideline Endorsement of the American Cancer Society Guideline. J Clin Oncol. 2017 Feb:JCO2016718478.

69. Wang $X$ et al. Management of salivary gland carcinomas - a review. Oncotarget. 2017 Jan 17;8(3):3946-56.

70. Tsai MS, et al. Mortality in tongue cancer patients treated by curative surgery: a retrospective cohort study from CGRD. PeerJ. 2016;4:e2794.

71. Eskiizmir $\mathrm{G}$ et al. Predictive and prognostic factors for patients with locoregionally advanced laryngeal carcinoma treated with surgical multimodality 
protocol. Eur Arch Otorhinolaryngol. 2017; 274(3): 1701-1711.

72. Nogueira JCC. Influência de métodos de esterilização nas propriedades físicas do substrato dental [tese]. Ribeirão Preto: Faculdade de Odontologia de Ribeirão Preto; 2010.

73. Pecharki GD, Cury JA, Paes Leme AF, Tabchoury CP, Del Bel Cury AA, Rosalen PL, et al. Effect of sucrose containing iron (II) on dental biofilm and enamel demineralization in situ. Caries Res. 20052005 Mar-Apr;39(2):123-9.

74. Rodrigues LK, Nobre Dos Santos M, Featherstone JD. In situ mineral loss inhibition by CO2 laser and fluoride. J Dent Res. 2006 Jul;85(7):617-21.

75. Goldstein GR \& Lerner T (1991) The effect of toothbrushing on a hybrid composite resin Journal of Prosthetic Dentistry 66(4) 498-500.

76. Yuan, J. C. C., Barão, V. A. R., Wee, A. G., Alfaro, M. F., Afshari, F. S., \& Sukotjo, C. (2017). Effect of brushing and thermocycling on the shade and surface roughness of CAD-CAM ceramic restorations. The Journal of Prosthetic Dentistry.

77. Weis $\mathrm{J}$, et al. International psychometric validation of an EORTC quality of life module measuring cancer related fatigue (EORTC QLQ-FA12). JNCI: Journal of the National Cancer Institute. 2017; 109(5).

78. Fang $\mathrm{YZ}$, Yang $\mathrm{S}, \mathrm{Wu}$ G. Free radicals, antioxidants and nutrition. Nutrition.2002; 18(10):872-879.

79. Oton-Leite AF, et al. Effect of low-level laser therapy on chemoradiotherapy-induced oral mucositis and salivary inflammatory mediators in head and neck cancer patients. Lasers in surgery and medicine. 2015; 47(4): 296-305.

80. Grippo JO, Simring M, Schreiner S. Attrition, abrasion, corrosion and abfraction revisited: a new perspective on tooth surface lesions. The Journal of the American Dental Association. 2004; 135(8): 1109-1118.

81. Barata TJE, Fernandes MILP, Fernandes JMA. Lesões cervicais não cariosas: condutas clínicas. Revista Odontológica do Brasil Central. 2010; 9(28).

82. Rathva V. Stress and periodontal disease. Guident. 2011; 4(10)

83. Tjäderhane L, et al. Dentin basic structure and composition—an overview. 
Endod Topics. 2012; 20(1): 3-29.

84. Rodrigues RB, et al. Influence of radiotherapy on the dentin properties and bond strength. Clinical oral investigations. 2017; 1-9.

85. Lieshout HF; Bots CP. The effect of radiotherapy on dental hard tissue-a systematic reviw. Clin Oral Investig. 2014; 18(1):17-24.

86. Qing P, et al. Effect of gamma irradiation on the wear behavior of human tooth dentin. Clinical oral investigations. 2016; 20(9):2379-2386.

87. Gomes-Silva W, et al. Head and neck radiotherapy may not increase gelatinase (metalloproteinase-2 and-9) expression or activity in teeth irradiated in vivo. Oral Surgery, Oral Medicine, Oral Pathology and Oral Radiology. 2017;124:175-182.

88. McGuire JD, et al. Type IV collagen is a novel DEJ biomarker that is reduced by radiotherapy. Journal of dental research. 2014; 93(10):1028-1034.

89. Bomfin LE, et al. 5-Fluorouracil induces inflammation and oxidative stress in the major salivary glands affecting salivary flow and saliva composition. Biochemical pharmacology. 2017; 145: 34-45.

90. Jensen SB, et al. Adjuvant chemotherapy in breast cancer patients induces temporary salivary gland hypofunction. Oral Oncol. 2008; 44(2):162-73

91. Toscano $\mathrm{N}$, et al. Oral implications of cancer chemotherapy. J Implant \& Advanced Clinical Dentistry. 2009;1(5):52-67

92. Benites BM. Determinação da presença de 5-FU na saliva de hamsters que receberam o quimioterápico pela técnica de Cromatografia Líquida de Alta Eficiência [tese]. Universidade de São Paulo, 2015.

93. Janoray G, et al. Long-term results of GORTEC 2000-01: A multicentric randomized phase III trial of induction chemotherapy with cisplatin plus 5fluorouracil, with or without docetaxel, for larynx preservation; 2015.

94. Ma, $\mathrm{Y}$ et al. Pharmacokinetic and Pharmacodynamic Analyses of 5Fluorouracil in East-Asian Patients with Nasopharyngeal Carcinoma. Clinical pharmacokinetics. 2016; 55(10):1205-1216.

95. Holding JD, et al. Measurement of platinum in saliva of patients treated with cisplatin. Annals of clinical biochemistry. 1999; 36(5): 655-659. 
96. Larsen MJ, Bruun C. A quimica da carie dentaria e flúor - mecanismo de ação. In Thylstrup, A.;Fejerskov, O. Cariologia clinica. Rio de Janeiro: Cultura Medica. 1995; cap.11: 231-258.

97. Pitts NB, et al. Dental caries. Nature reviews. Disease primers. 2017; 3: 17030.

98. Jansma J, et al. Natural and induced radiation caries: a SEM study. Am J Dent. 1993; 6(3):130-136

99. Walker MP, et al. Impact of radiotherapy dose on dentition breakdown in head and neck cancer patients, author manuscript. Pract Radiat Oncol. 2001; 1(3): 142-148.

100. Santos-Silva AR, et al. cGVHD - related caries and its shared features with other 'Dry-Mouth'- related caries. Brazilian Dental Journal. 2015; 26(4): 435-440.

101. Madrid CC et al. Structural analysis of enamel in teeth of Head-and-Neck cancer patients who underwent radiotherapy. Caries Research. 2017; 51(2): 119128

102. Mercut V, et al. Optical coherence tomography applications in tooth wear diagnosis. Romanian journal of morphology and embryology= Revue roumaine de morphologie et embryologie. 2017; 58(1):99.

103. Meurman JH, Drysdale T, Frank RM. Experimental erosion of dentin. European Journal of Oral Sciences. 1991; 99(6), 457-462.

104. Aksel H, et al. Effects of QMix and ethylenediaminetetraacetic acid on decalcification and erosion of root canal dentin. Microscopy research and technique, 2016; 79(11): 1056-1061.

105. Hedenbjörk-Lager $A$ et al. Collagen degradation and preservation of MMP8 activity in human dentine matrix after demineralization. Archives of oral biology. 2016; 68:66-72

106. Wang $\mathrm{L}$ et al. Wear resistance of packable resin composites after simulated toothbrushing test. Journal of Esthetic and Restorative Dentistry. 2004; 16(5), 303-314.

107. Leite ACE, Silva END, Melo NSD. Fatores de risco relacionados com o desenvolvimento do câncer bucal: uma revisão de literatura. RBAC. 2005; 48(1), 13-8. 
108. de Freitas RM, et al. Fatores de risco e principais alterações citopatológicas do câncer bucal: uma revisão de literatura. RBAC. 2016; 48(1): 13-8.

109. Santin GC, et al. Physical and adhesive properties of dental enamel after radiotherapy and bonding of metal and ceramic brackets. American Journal of Orthodontics and Dentofacial Orthopedics. 2015; 148(2): 283-292. 
Cronograma 



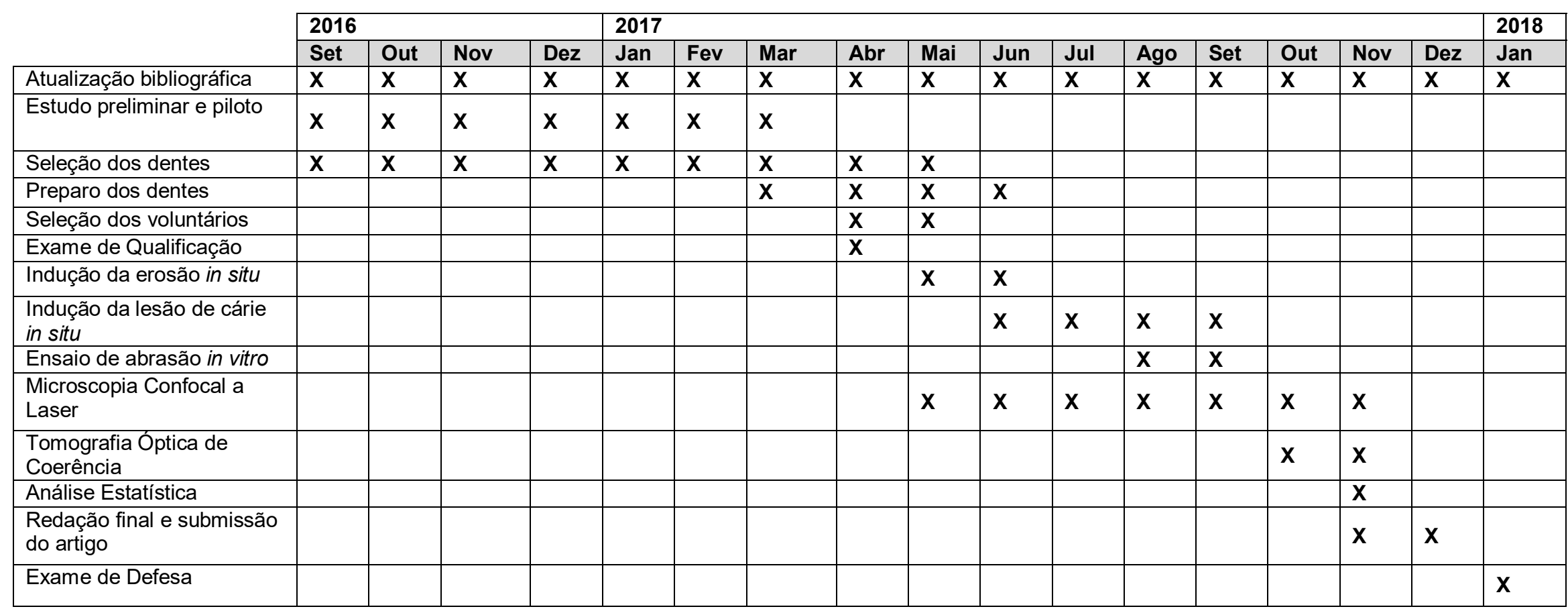



Anexo 



\section{ANEXO}

\section{ANEXO A - Parecer Consubstanciado do Comitê de Ética em Pesquisa}

FACULDADE DE
ODONTOLOGIA DE RIBEIRÃO Platoforma
PRETO/ FORP/ USP
PARECER CONSUBSTANCIADO DO CEP

\section{DADOS DO PROJETO DE PESQUISA}

Título da Pesquisa: INFLUÊNCIA DA RADIOTERAPIA, RADIO/QUIMIOTERAPIA E QUIMIOTERAPIA NA INDUÇÃO DE LESÃO DE CÁRIE, EROSÃO E ABRASÃO AO ESMALTE E DENTINA CORONÁRIA E RADICULAR DE DENTES PERMANENTES.

Pesquisador: Juliana Arid

Área Temática:

Versão: 1

CAAE: 61308416.4 .0000 .5419

Institulção Proponente:Universidade de Sao Paulo

Patrocinador Principal: Financiamento Próprio

DADOS DO PARECER

Número do Parecer: 1.795 .322

\section{Apresentação do Projeto:}

Os pesquisadores sabendo das alterações ocasionadas na cavidade bucal tanto pela radioterapia de cabeça e pescoço como pela quimioterapia, tem como o objetivo do presente estudo fazer uma análise externa das alterações sofridas pelo esmalte, dentina coronária e radicular de dentes permanentes de pessoas submetidas à radioterapia e/ou quimioterapia; avaliar, in situ, a erosão e indução de cárie em tais dentes; e avaliar a resistência à abrasão por escovação do substrato. Serão selecionados dentes extraídos de pacientes que foram submetidos ao tratamento radioterápico na região de cabeça e pescoço e ao tratamento quimioterápico no Hospital das Clínicas de Ribeirão Preto e no Hospital do Câncer de Barretos. Os dentes selecionados serão divididos em grupos de acordo com o tratamento antineoplásico a que foram previamente submetidos. Cada grupo terá um $\mathrm{n}=10$, em um total de 40 dentes: $\mathrm{G} 1$ - grupo controle: dentes extraídos de pacientes previamente à realização de qualquer tipo de tratamento antineoplásico ou saudáveis; G2- dentes extraídos de pacientes que já concluíram a radioterapia na região de cabeça e pescoço; G3 - dentes extraídos de pacientes que já concluíram o tratamento quimioterápico; G4 - dentes extraídos de pacientes que já concluíram o tratamento radioterápico e quimioterápico. Serão utilizados 40 fragmentos de esmalte, dentina coronária e

Endereço: Avenida do Café $\mathrm{s} / \mathrm{n}^{0}$

Bairro: Monte Alegre

UF: SP Municipio: RIBEIRAO PRETO

Telefone: (16)3315-0493 Fax: (16)3315-4102

CEP: $14.040-904$ 


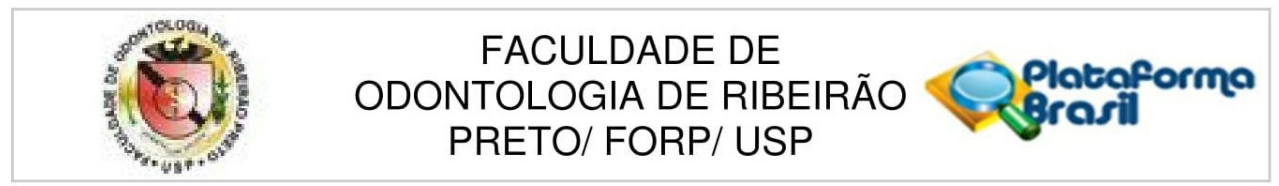

Continuação do Parecer: 1.795 .322

radicular que serão aleatoriamente distribuídos entre

10 voluntários. A primeira fase será análise do processo DES/RE nos substratos dentais in situ, na segunda fase a suscetibilidade dos tecidos a erosão in situ e na última fase a realização do teste de abrasão por meio de ensaio de escovação. As variáveis de resposta quantitativa serão perfil de desgaste, degrau formado, contagem de túbulos, perímetro dos túbulos dentinários, rugosidade da superfície, volume perdido e extensão do tecido desmineralizado. A variável qualitativa será a análise morfológica da superfície. Os dados obtidos pelos métodos quantitativos serão avaliados a normalidade e homogeneidade e se forem normais e homogêneos serão analisados estatisticamente com análise paramétrica (ANOVA e teste de Tukey-Kramer) para comparação entre os grupos, com nivel de significância estabelecido em $5 \%(p 0,05)$. As imagens obtidas em confocal e

microscopia óptica não serão analisadas estatisticamente uma vez que o objetivo da análise será de uma comparação qualitativa das diferentes condições experimentais propostas no estudo.

\section{Objetivo da Pesquisa:}

Realizar uma análise externa das alterações sofridas pelo esmalte, dentina coronária e radicular de dentes permanentes de pessoas submetidas à

RT e/ou QT; avaliar, in situ, a erosão e indução de cárie em tais estruturas; e avaliar a resistência abrasiva de tais estruturas em uma situação simulando a escovação dental.

\section{Avaliação dos Riscos e Benefícios:}

Riscos:

Para os voluntários:Poderá haver algum desconforto em função do uso do dispositivo intrabucalPara os doadores dos dentes: Poderá existir algum risco devido á extração dos dentes, como desconforto pós cirurgia, inchaço, sangramento, para diminuir tais incômodos deve ser seguidas todas orientações pós operatórias que o dentista recomendar.

Benefícios:

Para os voluntários: Os voluntários receberão instrução de higiene oral, será realizada profilaxia e estes receberão acompanhamento odontológico

durante o período em que estiverem utilizando o dispositivo intrabucal.Para os doadores dos dentes:É possível que este estudo não traga benefícios diretos. Mas ao final desta pesquisa, as informações que ele gerar, poderão trazer benefícios a outras pessoas.

Endereço: Avenida do Café s/no

Bairro: Monte Alegre

UF: SP Município: RIBEIRAO PRETO

Telefone: (16)3315-0493 Fax: (16)3315-4102

CEP: $14.040-904$ 


\section{FACULDADE DE ODONTOLOGIA DE RIBEIRÃO Platoforma PRETO/FORP/ USP}

Continuação do Parecer: 1.795.322

\section{Comentários e Considerações sobre a Pesquisa:}

Pesquisa relevante para a área da odontologia, apresenta referências bibliográficas atualizadas e os pesquisadores são plenamente habilitados para o desenvolvimento do projeto em tela.

\section{Considerações sobre os Termos de apresentação obrigatória:}

O projeto está apresentado de forma correta, cumpre todas as normativas estabelecidas pelo CEP da FORP/USP e CONEP.

\section{Recomendações:}

Aprovado.

Conclusões ou Pendências e Lista de Inadequações:

Aprovado.

Considerações Finais a critério do CEP:

Conforme deliberado na $197^{a}$ Reunião CEP/FORP/USP, realizada em 26/10/2016.

Este parecer foi elaborado baseado nos documentos abaixo relacionados:

\begin{tabular}{|c|c|c|c|c|}
\hline Tipo Documento & Arquivo & Postagem & Autor & Situação \\
\hline $\begin{array}{l}\text { Informações Básicas } \\
\text { do Projeto }\end{array}$ & $\begin{array}{l}\text { PB_INFORMAÇŌES_BÁSICAS_DO_P } \\
\text { ROJETO 803774.pdf }\end{array}$ & $\begin{array}{c}24 / 10 / 2016 \\
14: 32: 39\end{array}$ & & Aceito \\
\hline $\begin{array}{l}\text { TCLE / Termos de } \\
\text { Assentimento / } \\
\text { Justificativa de } \\
\text { Ausência }\end{array}$ & TCLEVoluntarioLesaodeCarie.docx & $\begin{array}{c}24 / 10 / 2016 \\
14: 32: 10\end{array}$ & Juliana Arid & Aceito \\
\hline $\begin{array}{l}\text { TCLE / Termos de } \\
\text { Assentimento / } \\
\text { Justificativa de } \\
\text { Ausência }\end{array}$ & TCLEVoluntariolnducaodeErosao.docx & $\begin{array}{c}24 / 10 / 2016 \\
14: 31: 49\end{array}$ & Juliana Arid & Aceito \\
\hline $\begin{array}{l}\text { TCLE / Termos de } \\
\text { Assentimento / } \\
\text { Justificativa de } \\
\text { Ausência }\end{array}$ & TCLEBarretos.docx & $\begin{array}{c}24 / 10 / 2016 \\
14: 31: 04\end{array}$ & Juliana Arid & Aceito \\
\hline Folha de Rosto & FolhadeRosto.pdf & $\begin{array}{c}10 / 10 / 2016 \\
09: 41: 47 \\
\end{array}$ & Juliana Arid & Aceito \\
\hline Outros & ColetaneaCartasDeclaracoes.pdf & $\begin{array}{c}09 / 10 / 2016 \\
14: 20: 11 \\
\end{array}$ & Juliana Arid & Aceito \\
\hline $\begin{array}{l}\text { TCLE / Termos de } \\
\text { Assentimento / } \\
\text { Justificativa de } \\
\text { Ausência } \\
\end{array}$ & TCLEDoadoresDosDentes.pdf & $\begin{array}{c}06 / 10 / 2016 \\
15: 57: 46\end{array}$ & Juliana Arid & Aceito \\
\hline Outros & DeclaracaoBiobancoDeDentes.pdf & $06 / 10 / 2016$ & Juliana Arid & Aceito \\
\hline
\end{tabular}

Endereço: Avenida do Café $\mathrm{s} / \mathrm{n}^{\circ}$

Bairro: Monte Alegre

UF: $\mathrm{SP}$

Municipio: RIBEIRAO PRETO

Telefone: (16)3315-0493 Fax: (16)3315-4102

CEP: $14.040-904$ 


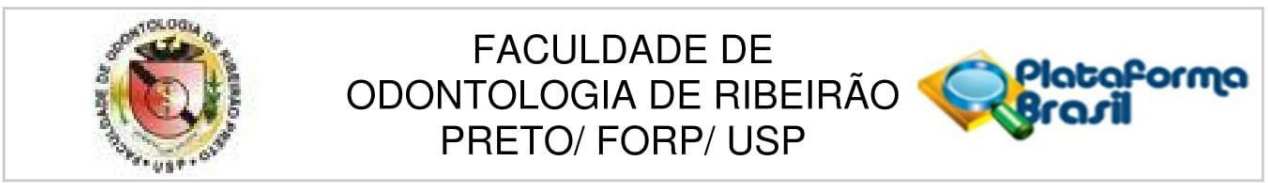

Continuação do Parecer: 1.795 .322

\begin{tabular}{|l|l|c|l|r|}
\hline Outros & DeclaracaoBiobancoDeDentes.pdf & $15: 31: 39$ & Juliana Arid & Aceito \\
\hline $\begin{array}{l}\text { Declaração de } \\
\text { Instituição e } \\
\text { Infraestrutura }\end{array}$ & AutorizacaolnfraEstrutura.pdf & $\begin{array}{c}06 / 10 / 2016 \\
15: 30: 49\end{array}$ & Juliana Arid & Aceito \\
\hline Cronograma & CronogramaPlataformaBrasil.docx & $\begin{array}{c}06 / 10 / 2016 \\
15: 28: 26\end{array}$ & Juliana Arid & Aceito \\
\hline $\begin{array}{l}\text { Projeto Detalhado / } \\
\text { Brochura } \\
\text { Investigador }\end{array}$ & ProjetoDePesquisa.docx & $\begin{array}{c}06 / 10 / 2016 \\
15: 16: 12\end{array}$ & Juliana Arid & Aceito \\
\hline
\end{tabular}

Situação do Parecer:

Aprovado

Necessita Apreciação da CONEP:

Não

RIBEIRAO PRETO, 27 de Outubro de 2016

Assinado por:

Simone Cecilio Hallak Regalo

(Coordenador)

Endereço: Avenida do Café $s / n^{\circ}$

Bairro: Monte Alegre

UF: SP

CEP: $\quad 14.040-904$

Telefone: (16)3315-0493

Fax: (16)3315-4102

E-mail: cep@forp.usp.br 